\title{
Fluid and Solid Inclusions in Host Minerals of Permian Pegmatites from Koralpe (Austria): Deciphering the Permian Fluid Evolution during Pegmatite Formation
}

\author{
Kurt Krenn *, Martina Husar and Anna Mikulics
}

Citation: Krenn, K.; Husar, M.; Mikulics, A. Fluid and Solid Inclusions in Host Minerals of Permian Pegmatites from Koralpe (Austria): Deciphering the Permian Fluid Evolution during Pegmatite Formation. Minerals 2021, 11, 638. https://doi.org/10.3390/min11060638

Academic Editors: Martin Smith, Magdalena Dumańska-Słowik, Beata Naglik, Tomasz Toboła and Giovanni Ruggieri

Received: 28 April 2021

Accepted: 11 June 2021

Published: 16 June 2021

Publisher's Note: MDPI stays neutral with regard to jurisdictional claims in published maps and institutional affiliations.

Copyright: (c) 2021 by the authors. Licensee MDPI, Basel, Switzerland. This article is an open access article distributed under the terms and conditions of the Creative Commons Attribution (CC BY) license (https:// creativecommons.org/licenses/by/ $4.0 /)$.
NAWI Graz Geocenter, Institute of Earth Sciences, University of Graz, 8010 Graz, Austria; martina.husar@edu.uni-graz.at (M.H.); anna.mikulics@edu.uni-graz.at (A.M.)

* Correspondence: kurt.krenn@uni-graz.at

Abstract: Fluid inclusions (FIs) and associated solids in host minerals garnet, tourmaline, spodumene, and quartz from six pegmatite fields of Permian origin at Koralpe (Eastern Alps) have been investigated. Although pegmatites suffered intense Eoalpine high-pressure metamorphic overprint during the Cretaceous period, the studied samples originate from rock sections with well-preserved Permian magmatic textures. Magmatic low-saline aqueous FIs in garnet domains entrapped as part of an unmixed fluid together with primary $\mathrm{N}_{2}$-bearing FIs that originate from a host rock-derived $\mathrm{CO}_{2}-\mathrm{N}_{2}$ dominated high-grade metamorphic fluid. This $\mathrm{CO}_{2}-\mathrm{N}_{2}$ fluid is entrapped as primary FIs in garnet, tourmaline, and quartz. During host mineral crystallization, fluid mixing between the magmatic and the metamorphic fluid at the solvus formed $\mathrm{CO}_{2}-\mathrm{N}_{2}-\mathrm{H}_{2} \mathrm{O}$-rich FIs of various compositional degrees that are preserved as pseudo-secondary inclusions in tourmaline, quartz, and as primary inclusions in spodumene. Intense fluid modification processes by in-situ host mineral-fluid reactions formed a high amount of crystal-rich inclusions in spodumene but also in garnet. The distribution of different types of FIs enables a chronology of pegmatite host mineral growth (garnet-tourmaline/quartzspodumene) and their fluid chemistry is considered as having exsolved from the pegmatite parent melt together with the metamorphic fluid from the pegmatite host rocks. Minimum conditions for pegmatite crystallization of ca. $4.5-5.5 \mathrm{kbar}$ at $650-750{ }^{\circ} \mathrm{C}$ have been constrained by primary FIs in tourmaline that, unlike to FIs in garnet, quartz, and spodumene, have not been affected by post-entrapment modifications. Late high-saline aqueous FIs, only preserved in the recrystallized quartz matrix, are related to a post-pegmatite stage during Cretaceous Eoalpine metamorphism.

Keywords: fluid inclusions; magmatic and metamorphic fluid; spodumene-garnet-tourmaline; insitu mineral reactions; Permian pegmatites; Eastern Alps

\section{Introduction}

A Permian extension event is well known in the Austroalpine basement of the Eastern Alps [1-7]. It is characterized by basaltic underplating that led to partial melting of metasediments at lower and middle crustal levels along with granulite and amphibolite facies metamorphism, respectively. In the latter case, melts crystallized in the form of pegmatites and granitoids that occur widely in the southern Austroalpine basement of the Eastern Alps. Melting experiments have shown that to generate peraluminous granitic melts in equilibrium with pegmatite staurolite, the pegmatite country rocks (metapelitic gneisses \pm paragonite, staurolite, and kyanite) had to be under anatectic conditions [8,9]. Besides the new age data of Austroalpine basement rocks, magmatism and high-temperature metamorphism during the Permian were another key argument for a fundamentally new interpretation of the nappe units of the Eastern Alps [10].

Most of the basement nappes and their sedimentary cover that have been formed in extensional graben systems were subsequently affected by Eoalpine (Cretaceous) metamorphism and deformation, generating the Koralpe-Wölz high-pressure nappe system (KWS). 
This system is characterized by a polymetamorphic nappe stack of lithologies with various Variscan, Permian, and Eoalpine imprints, where Permian pegmatites appear in units with variable Eoalpine overprint [11] (Figure 1a). While the pegmatite fields located in the KWS show the strongest overprint, a preserved magmatic texture is observed in many areas.

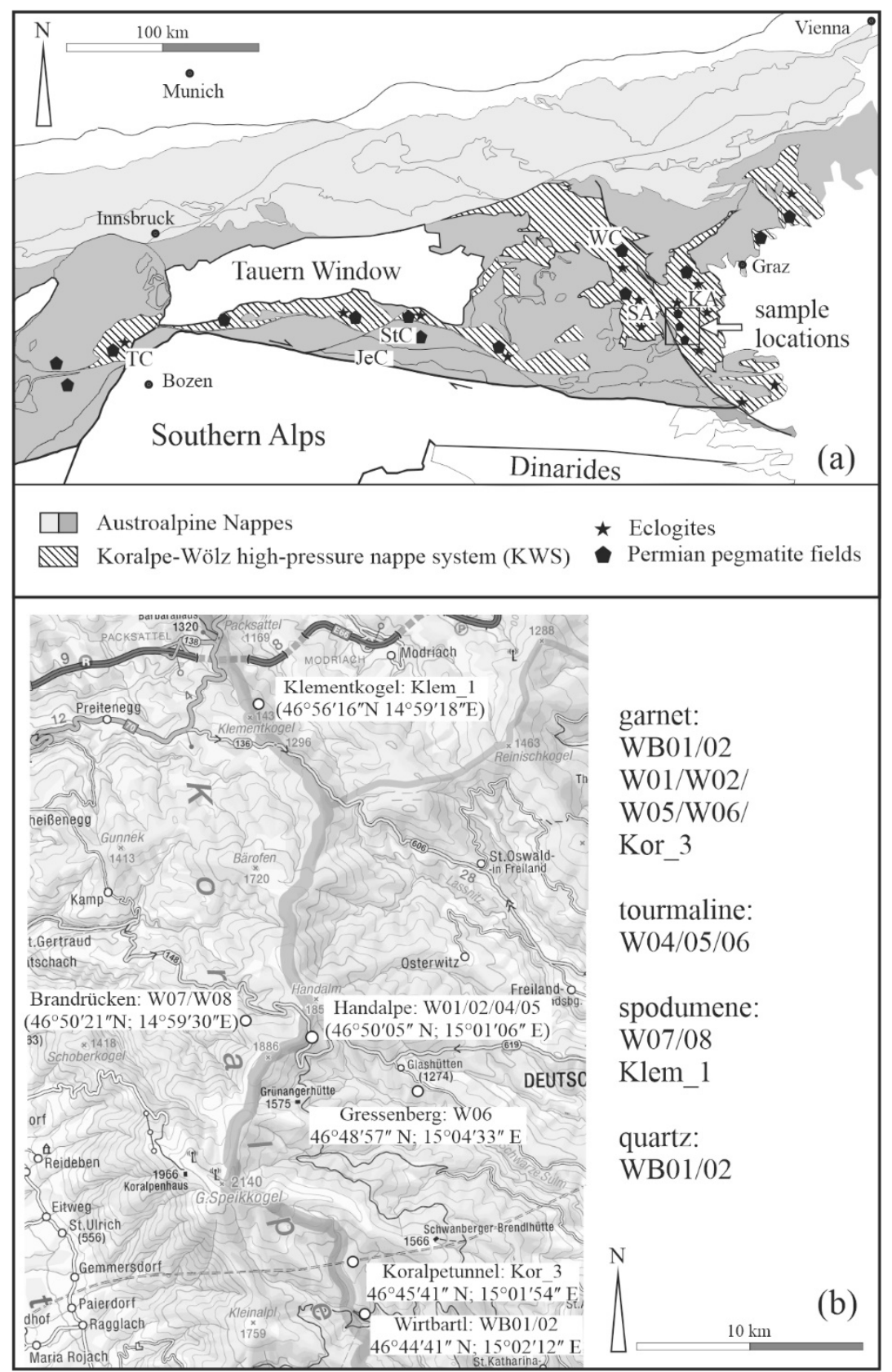

Figure 1. (a) Simplified geological map of the Eastern Alps showing W-E extent of the Koralpe-Wölz high-pressure nappe system (hatched areas) and approximate locations of Eoalpine eclogites (former Permian gabbros) and Permian pegmatite fields (map modified after Schmid et al. [10]). Note, that pegmatites occur also south and west of the wedge. The location of pegmatite samples in the Koralpe (KA) is indicated. Abbreviations: TC: Texel Complex; StC: Strieden Complex; JeC: Jenig Complex; WC: Wölz Complex; SA: Saualpe Complex; KA: Koralpe Complex. (b) Sample locations near the borderline between Styria (east) and Carinthia (west) given by GPS data. Sample numbers for the studied inclusions in host minerals are given in the column to the right. Topography taken from Amap Online (BEV). 
Information for the magmatic fluid present during pegmatite melt crystallization stages comes from melt- and fluid inclusion studies [12-20]. Both types of inclusions cannot usually be used to establish a complete and continuous report of the fluid/melt evolution during pegmatite crystallization because of potential secondary (post-solidification) trapping processes. However, inclusions provide valuable and otherwise unobtainable information on the melts and/or fluids for certain stages of the pegmatite evolution [18,21]. This information in conjunction with textural and mineral chemical data may then help to constrain the origin of fluids (i.e., primary magmatic versus metamorphic), to assess the conditions and processes of precipitation and crystallization of the pegmatites, respectively, by considering the extent of mixing of fluids of various sources $[14,15,17,22]$. By doing this, the operation of specific fluid/melt-modifying processes such as melt-melt and melt-fluid immiscibility or boiling can be inferred $[19,20]$.

Fluids exsolved from a crystallizing granitic melt are generally thought to be $\mathrm{H}_{2} \mathrm{O}$ rich with negligible to moderate $\mathrm{CO}_{2}$ contents whereas more $\mathrm{CH}_{4}-\mathrm{N}_{2}$-rich fluids are interpreted as ultimately metamorphic in origin that formed in equilibrium with graphite and $\mathrm{NH}_{4}$-containing micas and/or feldspars in the pegmatite country rocks [13-17,23]. $\mathrm{CH}_{4}$-rich fluids may originate from magmatic $\mathrm{CO}_{2}$-rich fluids under changing conditions, nevertheless, $\mathrm{CO}_{2}$-rich fluids are less likely to have evolved from differentiated granitic magma due to the very low solubility in such magma [17,24].

Considering this approach, magmatic pegmatite minerals like garnet, tourmaline, spodumene, and quartz from six selected pegmatite fields of the Koralpe with Permian origin have been selected. The aim of this study is (1) to characterize the composition of fluids evolving during pegmatite formation in a high-grade metamorphic environment; (2) to decipher a possible fluid evolution during pegmatite crystallization stages and metamorphism and (3) to calculate minimum pressures of fluid entrapment for pegmatite crystallization based on density data of representative FIs.

\section{Geological Setting}

The Saualpe-Koralpe Complex is part of the KWS and predominantly built up by sedimentary rocks that experienced at least two metamorphic events: a Permian lowpressure/high-temperature (LP/HT) and an Eoalpine Cretaceous high-pressure/medium temperature (HP/MT) event [10]. The KWS comprises areas west and east of the Tauern Window (TW) and contains pegmatite bearing units that consist mainly of staurolite and/or alumosilicates bearing micaschists and paragneisses. Typically, dm-sized andalusite crystals, which were transformed into kyanite-paramorphs as a result of Eoalpine metamorphism, are known as "Disthen-Paramorphosenschiefer" [25]. This transformation from low-pressure polymorph andalusite towards pressure-dominated kyanite is also well observable in pegmatites, indicating that the Al-rich silicic melt crystallized within the LP/HT field. Cretaceous subduction overprinted Permian magmatic rocks (i.e., mafics and pegmatites) in the central part of the KWS by forming eclogites and lenses of foliationparallel meta-pegmatites. Eclogites occur predominantly in the southernmost areas of the KWS whereas Permian pegmatites with Eoalpine overprint spread throughout the KWS (Figure 1a).

Classical thermobarometry for calculation of Permian metamorphic conditions in the KWS is challenging, due to the intense Eoalpine overprint that affected the rock units. Rocks south of the KWS with weak Eoalpine imprint were considered for the calculations of Permian metamorphism. In the Strieden Complex (StC in Figure 1a), PT conditions range from $2.5-5 \mathrm{kbar}$ at $500-750{ }^{\circ} \mathrm{C}[5,11]$. Representative P-T conditions and age data from monazite for the Permian metamorphic event of $450-530{ }^{\circ} \mathrm{C} / 2.4-4.2 \mathrm{kbar}$ at $275 \pm 25 \mathrm{Ma}$ have been calculated from andalusite bearing mica schists of the Jenig Complex (JeC in Figure 1a) further south of the Strieden Complex [11]. Conditions from meta-pegmatites in the Koralpe-Saualpe Complex within the KWS show upper-pressure limits between 3 and $4 \mathrm{kbar}$ and minimum crystallization temperatures around $650{ }^{\circ} \mathrm{C}$. Data are based on magmatic mineral equilibria in peraluminous (andalusite-sillimanite 
equilibrium) granitic melt systems [26]. Magmatic garnets from these pegmatite samples are characterized by almandine-spessartine solid solutions with low Ca-contents and by major and trace element characteristics, unaffected in their cores from Eoalpine highpressure overprint. This enables age determinations of the Permian magmatic event from ca. 280 to $230 \mathrm{Ma}[6,26,27]$.

Eoalpine peak metamorphism in the Koralpe Complex is best constrained at about $625-730{ }^{\circ} \mathrm{C} / 22-28 \mathrm{kbar}$ for eclogites [28] and $700 \pm 68$ to $600 \pm 63{ }^{\circ} \mathrm{C}$ at $10-15 \mathrm{kbar}$ for metapelites [29]. Ages related to this event are between 90 and $95 \mathrm{Ma}[28,30]$.

\section{Location and Petrography of Pegmatite Samples}

For the fluid inclusion study, two pegmatite samples (WB01 and WB02) from the southern Koralpe at the Wirtbartl pegmatite field $\left(46^{\circ} 44^{\prime} 41^{\prime \prime} \mathrm{N} ; 15^{\circ} 02^{\prime} 12^{\prime \prime} \mathrm{E}\right)$, comparable to samples HS00704 and HS00304 of Habler et al. [26], were picked up by W. Postl in the year 2005 (Postl pers. com., Figure 1b). Both samples have been selected for inclusion studies in garnet and quartz. Garnet from this area yield Sm-Nd ages of $251.3 \pm 7.2 \mathrm{Ma}$ (cores) and $229.2 \pm 3.2 \mathrm{Ma}$ (rims) $[27,28]$. To the north, a garnet sample (Kor_3) was taken directly from the Koralpetunnel portal $\left(46^{\circ} 45^{\prime} 41^{\prime \prime} \mathrm{N} ; 15^{\circ} 01^{\prime} 54^{\prime \prime}\right.$ E). Further samples in the central Koralpe used for inclusion studies in garnet (W01; W02; W05) and tourmaline (W04; W05) have been taken at the road to the Handalpe area $\left(46^{\circ} 50^{\prime} 05^{\prime \prime} \mathrm{N} ; 15^{\circ} 01^{\prime} 06^{\prime \prime} \mathrm{E}\right)$ and at Gressenberg (W06; 46 $48^{\prime} 57^{\prime \prime} \mathrm{N} ; 1^{\circ} 04^{\prime} 33^{\prime \prime}$ E). Samples W07 and W08 from the Brandrücken area $\left(46^{\circ} 50^{\prime} 21^{\prime \prime} \mathrm{N} ; 14^{\circ} 59^{\prime} 30^{\prime \prime}\right.$ E) as well as sample Klem_1 from Klementkogel, located $500 \mathrm{~m}$ NE from the Klementkogel peak ( $\left.46^{\circ} 56^{\prime} 16^{\prime \prime} \mathrm{N} 14^{\circ} 59^{\prime} 18^{\prime \prime} \mathrm{E}\right)$ at the northern Koralpe, were selected for inclusion studies in spodumene (Figure 1b). All samples are located near the border between Styria and Carinthia.

Host rocks of pegmatites in all study areas are micaschists, paragneisses, laminated carbonatic amphibolites, and marbles of sedimentary origin [31]. Macroscopically, pegmatites consist of garnet, tourmaline, muscovite, feldspar porphyroclasts (K-feldspar and Na-rich plagioclase) \pm kyanite-paramorphs, all embedded in a matrix of recrystallized quartz aggregates (Figure 2a,b). Garnet at Wirtbartl area (WB01/02) shows a size up to $1.5 \mathrm{~cm}$, embedded in a fine-grained matrix consisting of white mica, kyanite paramorphs, and quartz (Figure $2 b, c)$. It is fractured with stained characteristics and contains a large amount of solid and fluid inclusions, predominantly in its dark areas (Figure 2c). Close to the rim, white mica (muscovite), kyanite, and quartz occur; chlorite and/or biotite are not present. Considering the observed mineral assemblage, kyanite and muscovite must replace garnet and andalusite, which results in kyanite paramorphs after magmatic andalusite (Figure 2d). Tourmaline grains (samples WB01/02) appear poikiloblastic along their margins by enclosing quartz grains containing well-preserved FIs (white arrows in Figure 2e). In places, tourmaline is surrounded by aggregates of kyanite + muscovite and matrix quartz, suggesting tourmaline as part of the Permian mineral assemblage along with former andalusite and garnet (Figure 2f). Garnets from pegmatite sample Kor_3 are up to $7 \mathrm{~mm}$ in size, euhedral, and partly consumed by biotite. They are embedded in a matrix of quartz, alkalifeldspar (albite, orthoclase), kyanite, and muscovite. Accessory minerals are rutile, apatite, monazite, zircon, sulfides (pyrite and bornite), and tourmaline. Pegmatites at Handalpe and Gressenberg areas (W01/02/05/06) contain garnets with a size up to $1.8 \mathrm{~cm}$. Tourmaline crystals contain solid inclusions like quartz and muscovite and rarely kyanite, apatite, plagioclase, and graphite. In general, tourmaline zoning has no effect on solid mineral inclusion content. 


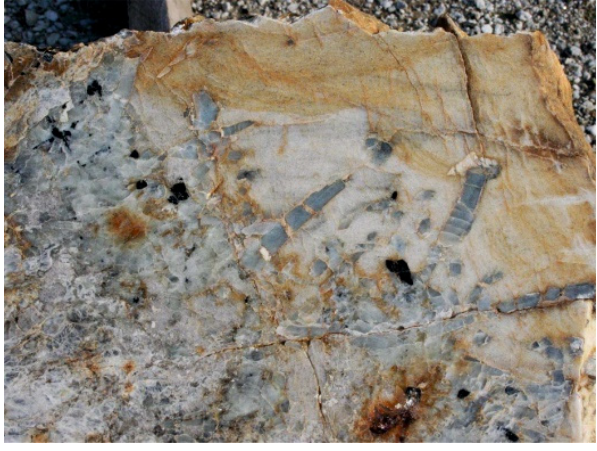

(a)

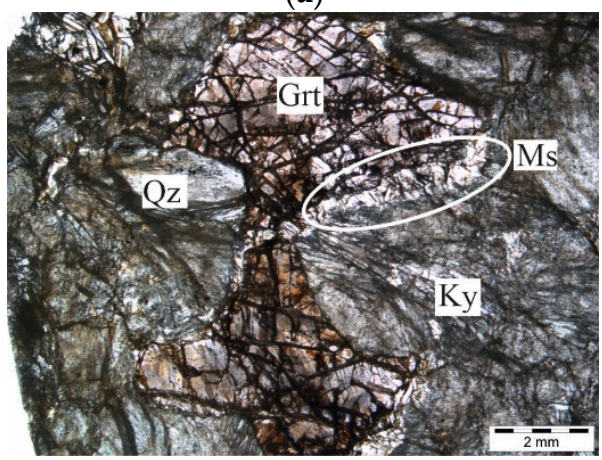

(c)

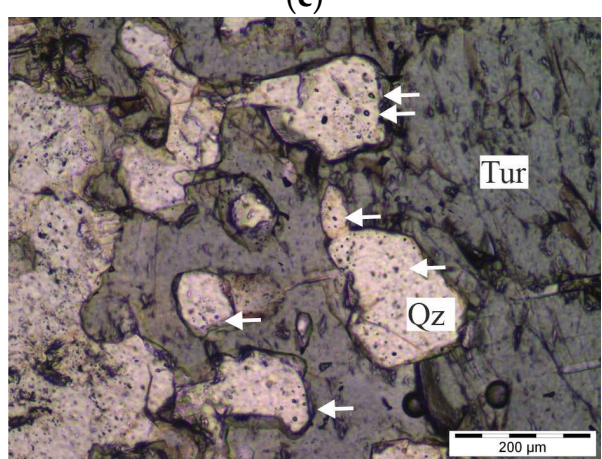

(e)

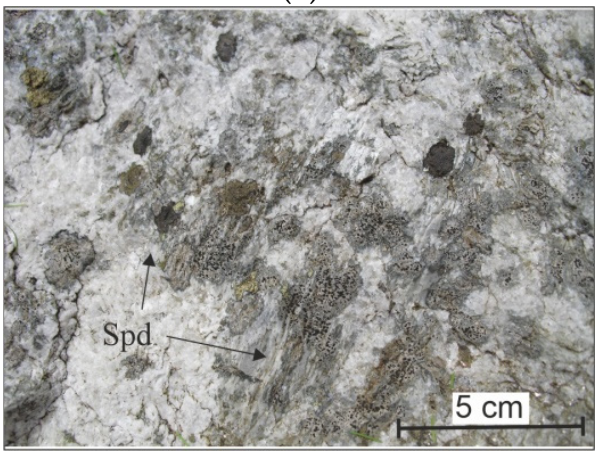

(g)

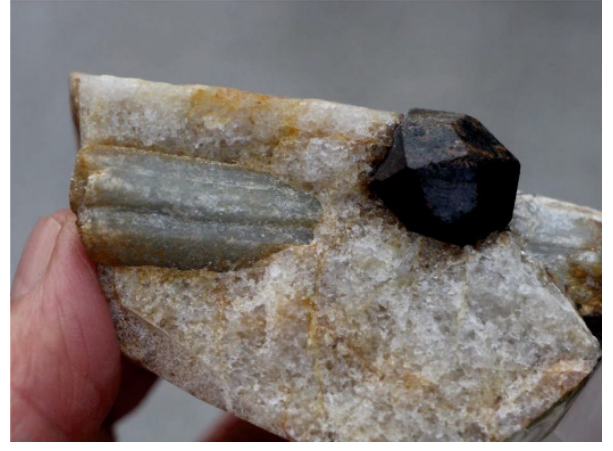

(b)

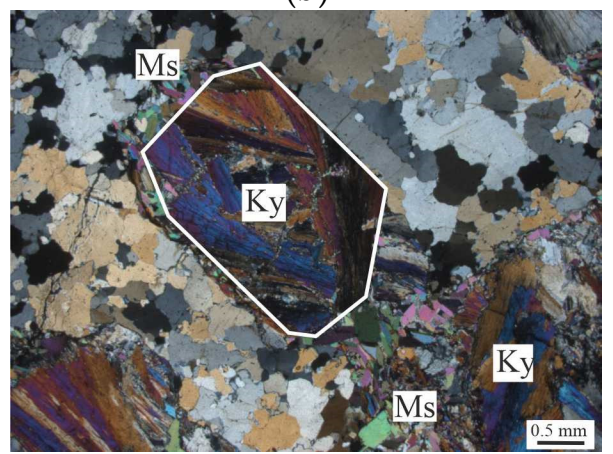

(d)

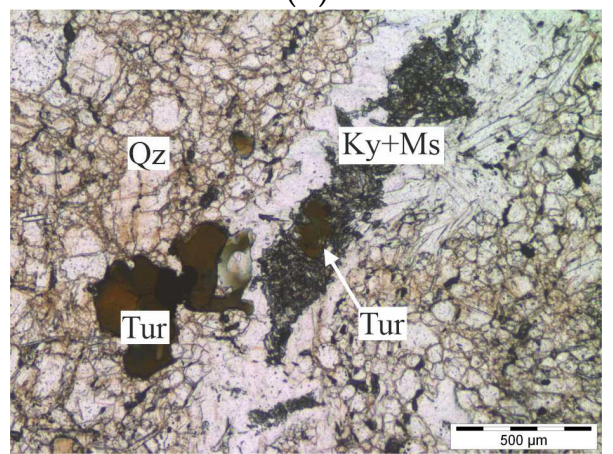

(f)

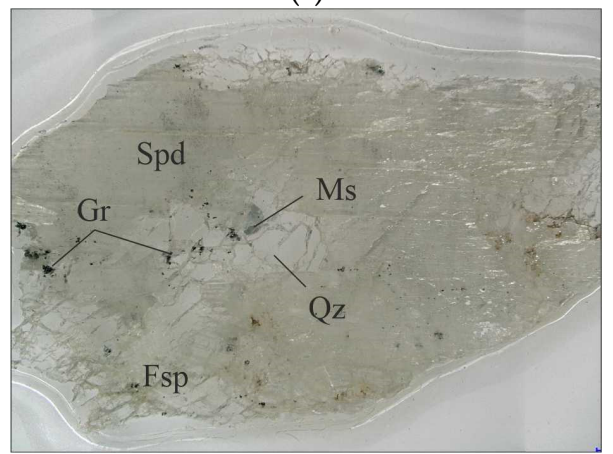

(h)

Figure 2. Pegmatite mineral assemblage. (a) Pegmatite with a magmatic texture containing kyanite paramorphs (blue) in a very fine-grained quartz matrix; tourmaline and garnet (bottom of image) occur accessorily. The length of the block is ca. $60 \mathrm{~cm}$. (b) Hand specimen of fine-grained recrystallized quartz matrix surrounding a large kyanite paramorph crystal and a garnet. Thumb for scale. (c) A thick section of garnet porphyroblasts (Grt) embedded in a matrix consisting of muscovite (Ms), kyanite (Ky), and quartz (Qz). Garnet shows intense cracking. Light and dark areas in garnet contain 
fluid and solid inclusions. Muscovite aggregates close to garnet grain boundaries are shown inside the ellipse. (d) Kyanite and muscovite replace andalusite (kyanite paramorphs after andalusite), best visible in the former shape of andalusite (white frame) (thin section). (e) Tourmaline poikiloblast (Tur) containing quartz inclusions with a high amount of FIs (white arrows). (f) Tourmaline enclosed in quartz matrix but also surrounded by fine-grained kyanite + muscovite and quartz aggregates. Kyanite + muscovite are considered to replace a former andalusite crystal that formed in equilibrium with tourmaline. (g) Outcrop section of a pegmatite containing large spodumene crystals (Spd) with white color and intense cleavage. (h) A thick section of a spodumene crystal ( $5 \mathrm{~cm}$ in length) associated with quartz, muscovite, feldspar (Fsp), and graphite (Gr).

The pegmatite field at Brandrücken area contains concordant spodumene-bearing meta-pegmatites hosted by amphibolites. The contact zone is characterized by biotitization and the formation of holmquistite [31,32]. The mineral assemblage consists of grayish to greenish spodumene crystals, with an average size of $2-3 \mathrm{~cm}$ (up to $15 \mathrm{~cm}$ ) showing late overgrowth of the matrix composed of quartz and feldspar (mainly albite and occasionally microcline) (Figure 2g). Additional muscovite, beryl, tourmaline, apatite, as well as accessory graphite, cassiterite, triphyline, ferrisicklerite, pyrochlore, and zircon, occur [31,32]. Pegmatites at Klementkogel intruded into garnet micaschists ( \pm kyanite and staurolite) and are mainly composed of K-feldspar, albite, quartz, and muscovite. Beryl, cassiterite, spodumene, and apatite occur accessorily [33]. Spodumene is up to $10 \mathrm{~cm}$ in size and shows a pale yellowish-green to pale pink shading towards the edges (Figure $2 \mathrm{~h}$ ).

\section{Materials and Methods}

\subsection{Electron Microprobe Quantitative}

Major element compositions of selected garnet fragments were obtained with a JEOL JSM 6310 scanning electron microprobe attached with EDS and WDS systems at the NAWI Graz Geocenter, University of Graz (Graz, Austria), using 15 kV accelerating voltage and $5 \mathrm{nA}$ beam current. The following standards were used: adular ( $\mathrm{Si}, \mathrm{Al})$, garnet $(\mathrm{Mg}, \mathrm{Fe})$, titanite $(\mathrm{Ca}, \mathrm{Ti})$, rhodonite $(\mathrm{Mn})$. Element mole fractions were obtained to determine major element zonation profiles and major element chemistries (XFe, XMn, XMg, XCa) of garnet domains close to the studied FIs.

\subsection{Electron Microprobe Qualitative}

Images of open cavities have been performed using a ZEISS DSM 982 (Gemini) scanning electron microprobe using $5 \mathrm{kV}$ accelerating voltage and $3 \mathrm{nA}$ beam current and a Jeol JXA-8530F Plus Field Emission Electron Probe with acceleration voltage of $15 \mathrm{kV}$ and a beam current of $10 \mathrm{nA}$ at the NAWI Graz Geocenter, University of Graz (Graz, Austria). The following standards were used: garnet ( $\mathrm{Si}, \mathrm{Al}, \mathrm{Fe}, \mathrm{Ca})$, jadeite (Na), rhodonite (Mn), microcline $(\mathrm{K})$, chromite $(\mathrm{Cr})$, rutile $(\mathrm{Ti})$.

\subsection{Microthermometry}

Microthermometric measurements of the FIs were performed using a Linkam THSMG600 heating and freezing stage covering a temperature range from $-196{ }^{\circ} \mathrm{C}$ to $+600{ }^{\circ} \mathrm{C}$ at the NAWI-Graz Geocenter (Graz, Austria). During cooling and heating, phase transitions were observed with an Olympus petrographic microscope equipped with an $80 \times$ ULWD objective. The Synthetic Fluid Inclusion Reference Set (Bubbles Inc., Blacksburg, VA, USA) was used for stage calibration. Temperature measurements are reproducible to within $0.2{ }^{\circ} \mathrm{C}$ at a heating rate of $0.1^{\circ} \mathrm{C} \mathrm{min}^{-1}$. Calculations of fluid densities and salinities were performed with the program Bulk by using the appropriate equations of state (EOS) after Oakes et al. [34] and Duan et al. [35] as well as salinity calculations after Naden [36]. For nitrogen inclusions, EOS after Jacobsen et al. [37] were used. Isochores for representative high-density FIs have been calculated using the program Isoc. Bulk and Isoc are part of the software package FLUIDS 1 [38]. All FIs were at least initially cooled to below $-100{ }^{\circ} \mathrm{C}$ $\left(-190{ }^{\circ} \mathrm{C}\right.$ for $\mathrm{N}_{2}$-FIs) and subsequently heated to determine the temperatures of phase 
transitions. Depending on the chemical system for any given FI, the following parameters are documented ( $\mathrm{L}=$ liquid; $\mathrm{V}=$ vapor; $\mathrm{S}=$ solid phase): $T_{\mathrm{e}}(\mathrm{ice})$ eutectic temperature or apparent eutectic temperature of ice melting (e.g., IceV $\rightarrow$ IceLV); $T_{\mathrm{e}}$ means the minimum temperature of liquid stability in a specified system associated with a unique characteristic mixture of the components [39]. It was used to identify the aqueous fluid system after Davis et al. [40] and Goldstein and Reynolds [41]; $T_{\mathrm{m}}$ (Ice) final melting temperature of ice (IceLV $\rightarrow \mathrm{LV}$ ); final melting temperatures of $\mathrm{CO}_{2} \pm \mathrm{N}_{2}$ are given as $T_{\mathrm{m}}$ (car). By using the final melting temperature of hydrohalite $\left[T_{\mathrm{m}}(\mathrm{HH})\right]$ together with $\left[T_{\mathrm{m}}(\right.$ Ice) $)$, the corresponding fluid compositions in $\mathrm{NaCl} / \mathrm{CaCl}_{2}$ ratios were determined with diagrams from Oakes et al. [34] and explanations in Bodnar [42]. Homogenization temperatures of the carbonic vapor bubble $\left[T_{\mathrm{h}}(\mathrm{car})\right]$ as well as total homogenization temperatures $\left[T_{\mathrm{h}}(\right.$ tot $)$ $(\mathrm{LV} \rightarrow \mathrm{L}$ or $\mathrm{V})]$ were measured to obtain densities and minimum temperatures for the formation of homogeneously trapped FIs. A summary of microthermometric properties of all types of FIs investigated in this study is presented in Table 1.

\subsection{Micro-Raman Spectroscopy}

To identify fluid components and solid phases of the investigated inclusions, unpolarized Raman spectra in the confocal mode were obtained with a HORIBA JOBIN YVON LabRam-HR 800 Raman micro-spectrometer at the NAWI Graz Geocenter, University of Graz (Graz, Austria). Crystals and fluids within polished sections were excited at room temperature (RT) with a $532 \mathrm{~nm}$ emission line of a $50 \mathrm{~mW} \mathrm{Nd}-\mathrm{YAG}$ and $632.2 \mathrm{~nm}$ of a $30 \mathrm{~mW}$ He-Ne laser through an OLYMPUS $100 \times$ objective (N.A. 0.9). The laser spot on the surface had a diameter of approximately $4 \mu \mathrm{m}$. The light was dispersed by a holographic grating with 1800 grooves $/ \mathrm{mm}$. The slit width was set to $100 \mu \mathrm{m}$. The dispersed light was collected by a $1024 \times 256$ nitrogen-cooled open electrode CCD detector. Band shifts were calibrated by regularly adjusting the zero position of the grating and controlled by measuring the Rayleigh line of the incident laser beam. The detection range involving solid, liquid, and gas phases lies between 120 and $3800 \mathrm{~cm}^{-1}$. Based on the Raman spectra, the compositions of FIs in terms of $\mathrm{mol} \%$ of the fluid species have been calculated using Equation (2) given by Burke [43]. To compare and identify Raman spectra, tables in Frezzotti et al. [44] have been used.

Table 1. Summary of fluid inclusion properties.

\begin{tabular}{|c|c|c|c|c|c|c|c|}
\hline Host & FI-Type & Texture & \multicolumn{2}{|c|}{ Chemistry } & \multicolumn{3}{|c|}{ Phases } \\
\hline Grt & Type-N & $\mathrm{p}$ & \multicolumn{2}{|c|}{$\mathrm{N}_{2}$} & \multicolumn{3}{|c|}{$\mathrm{L}_{\mathrm{N} 2} \pm \mathrm{S}$} \\
\hline Grt & Type-A & $\mathrm{p}$ & \multicolumn{2}{|c|}{$\mathrm{H}_{2} \mathrm{O}-\mathrm{NaCl}-\mathrm{CaCl}{ }_{2} \pm \mathrm{MgCl}_{2}$} & \multicolumn{3}{|c|}{$\mathrm{Laqu} \pm \mathrm{Vaqu} \pm \mathrm{S}$} \\
\hline Grt & Type-G & $\mathrm{p}$ & \multicolumn{2}{|c|}{$\mathrm{CO}_{2}-\mathrm{N}_{2}$} & \multicolumn{3}{|c|}{ Lcar $\pm \mathrm{S}$} \\
\hline Tur & Type-T1 & $\mathrm{p}$ & \multirow{2}{*}{\multicolumn{2}{|c|}{$\begin{array}{c}\mathrm{CO}_{2}-\mathrm{N}_{2} \\
\mathrm{CO}_{2}-\mathrm{N}_{2} \pm \mathrm{CH}_{4}-\mathrm{H}_{2} \mathrm{O}-\mathrm{NaCl}-\mathrm{CaCl}_{2} \pm \\
\mathrm{MgCl}_{2}\end{array}$}} & \multicolumn{3}{|c|}{ Lcar } \\
\hline Tur & Type-T2 & ps-s & & & \multicolumn{3}{|c|}{ Laqu + Lcar } \\
\hline Spd & Type-S & p-ps & \multicolumn{2}{|c|}{$\mathrm{CO}_{2}-\mathrm{N}_{2}-\mathrm{H}_{2} \mathrm{O}-\mathrm{NaCl}-\mathrm{CaCl}_{2} \pm \mathrm{MgCl}_{2}$} & \\
\hline Spd $^{*}$ & Type-S & p-ps & \multirow{2}{*}{\multicolumn{2}{|c|}{$\begin{array}{c}\mathrm{CO}_{2}-\mathrm{N}_{2}-\mathrm{H}_{2} \mathrm{O}-\mathrm{NaCl}^{-\mathrm{CaCl}_{2}} \pm \mathrm{MgCl}_{2}-\mathrm{M}_{2} \\
\mathrm{CO}_{2}\end{array}$}} & \multicolumn{3}{|c|}{ Laqu + Lcar \pm Vcar $+S$} \\
\hline $\mathrm{Qz}$ & Type-Q1 & $\mathrm{p}$ & & & \multirow{2}{*}{\multicolumn{3}{|c|}{ Laqu + Lcar }} \\
\hline $\mathrm{Qz}$ & Type-Q2 & ps-s & \multicolumn{2}{|c|}{$\mathrm{CO}_{2}-\mathrm{N}_{2}-\mathrm{H}_{2} \mathrm{O}-\mathrm{NaCl}-\mathrm{CaCl}_{2} \pm \mathrm{MgCl}_{2}$} & & & \\
\hline$\hat{\mathrm{Q} z}$ & Type-Q3 & ps-s & \multicolumn{2}{|c|}{$\mathrm{H}_{2} \mathrm{O}-\mathrm{NaCl}-\mathrm{CaCl}_{2} \pm \mathrm{MgCl}_{2}$} & \multicolumn{3}{|c|}{ Laqu + Vaqu } \\
\hline FI-Type & & Solids & $T_{\mathrm{m}}(\mathrm{car})\left({ }^{\circ} \mathrm{C}\right)$ & $T_{\mathrm{e}}$ (ice) $\left({ }^{\circ} \mathrm{C}\right)$ & $T_{\mathrm{m}}(\mathrm{HH})\left({ }^{\circ} \mathrm{C}\right)$ & $T_{\mathrm{m}}($ ice $)\left({ }^{\circ} \mathrm{C}\right)$ & $T_{\mathrm{m}}(\mathrm{Cla})\left({ }^{\circ} \mathrm{C}\right)$ \\
\hline Type-N & & Ms, Cal, Rt, Grt & & & & & \\
\hline Type-A & & Rds, Ap, Ilm, Ky & & -61.9 to -58.0 & -38.5 to -33.0 & -8.7 to -4.1 & \\
\hline Type-G & ] & $\mathrm{Zrn}, \mathrm{Qz}$ & -65.3 to -56.6 & & & & \\
\hline Type-T1 & & & -60.0 to -58.7 & & & & \\
\hline Type-T2 & & & -61.8 to -58.3 & -54.2 to -46.0 & -27.2 to -23.8 & -4.5 to -3.1 & 8.5 to 14.5 \\
\hline Type-S & Z & Qz, Zbl, Ms, Cst & -58.0 to -57.5 & -55.2 to -53.6 & -28.0 to -23.2 & -7.7 to -4.2 & 7.9 to 13.2 \\
\hline Type-S & $\zeta$ & Wo, $\mathrm{Ky}, \mathrm{Fl}, \mathrm{Ab}, \mathrm{Zrn}$ & -57.6 to -56.7 & -53.8 to -50.7 & -23.7 to -23.1 & -6.1 to -2.2 & 0.0 to 13.6 \\
\hline Type-Q1 & & & -60.0 to -59.2 & & & & \\
\hline Type-Q2 & & & $\sim-59.6$ & -42.2 to -48.4 & -33.0 to -29.2 & -11.2 to -9.0 & \\
\hline Type-Q3 & & & & -60.0 to -40.0 & -37.8 to -29.3 & -19.0 to -11.0 & \\
\hline
\end{tabular}


Table 1. Cont.

\begin{tabular}{|c|c|c|c|c|c|c|}
\hline FI-Type & $T_{\mathrm{h}}(\mathrm{car}) \rightarrow \mathrm{L}\left({ }^{\circ} \mathrm{C}\right)$ & 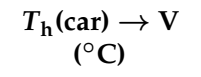 & $T_{\mathrm{h}} \operatorname{tot}(\mathrm{aqu}) \rightarrow \mathrm{L}$ & $T_{\mathrm{h}} \operatorname{tot}(\mathrm{car}) \rightarrow \mathrm{L}$ & Density & Salinity \\
\hline Type-N & -150.0 to $-148.3^{*}$ & & & & $0.43-0.47$ & \\
\hline Type-A & & & 192.6 to 321.0 & & $0.76-0.99$ & $7.2-12.8$ \\
\hline Type-G & -60.0 to 22.0 & & & & $0.61-1.16$ & \\
\hline Type-T1 & -54.9 to -32.8 & & & & $0.80-0.85$ & \\
\hline Type-T2 & -47.4 to 7.7 & & & 215.1 to 294.5 & $0.18-0.87$ & $3.2-6.9$ \\
\hline Type-S & 0.3 to 17.0 & & & 302.1 to 583.0 & $0.72-1.11$ & $7.3-11.6$ \\
\hline Type-S & 18.0 to 24.0 & 17.6 to 25.3 & & 255.8 to 311.7 & $0.68-0.89$ & $3.8-9.6$ \\
\hline Type-Q1 & -25.3 to -5.7 & -41.0 to -31.1 & & & n.c. & \\
\hline Type-Q2 & -23.2 to -17.2 & & 130.5 to 206.0 & n.o. & n.c. & $13.0-15.0$ \\
\hline Type-Q3 & & & 125.5 to 176.2 & & $1.02-1.10$ & $15.0-20.2$ \\
\hline
\end{tabular}

$T_{\mathrm{m}}(\mathrm{car})=$ temperature of last melting of carbonic liquid phase; $T_{\mathrm{e}}(\mathrm{ice})=$ temperature of eutectic ice melting; $T_{\mathrm{m}}(\mathrm{HH})=$ temperature of final melting of hydrohalite; $T_{\mathrm{m}}$ (ice) = temperature of final melting of ice; $T_{\mathrm{m}}(\mathrm{Cla})=$ temperature of final clathrate melting; $T_{\mathrm{h}}(\mathrm{car}) \rightarrow$ $\mathrm{L}=$ temperature of homogenization of the carbonic vapor bubble to the liquid; $T_{\mathrm{h}}(\mathrm{car}) \rightarrow \mathrm{V}=$ temperature of homogenization of the carbonic vapor bubble to the vapor; $T_{\mathrm{h}} \operatorname{tot}(\mathrm{aqu}) \rightarrow \mathrm{L}=$ total homogenization temperature of aqueous inclusion to the liquid; $T_{\mathrm{h}}$ tot(car) $\rightarrow$ $\mathrm{L}=$ total homogenization temperature of carbonic inclusion to the liquid; ${ }^{*}=$ homogenization data of $\mathrm{N}_{2}$ bubble to liquid; $\mathrm{p}=$ primary; ps = pseudosecondary; $\mathrm{s}=$ secondary; $\mathrm{Spd}^{*}=$ Spodumen sample from Klementkogel; density in $\mathrm{g} / \mathrm{cm}^{3}$; salinity (total) in equiv. mass $\%$; phases observed at room temperature; n.c. = not calculated; n.o. not observed; Mineral abbreviations after Whitney and Evans [45].

\section{Results}

\subsection{Fluid Inclusion Study}

5.1.1. Fluid Inclusions in Magmatic Garnets (Type-N, Type-A, Type-G)

Three types of FIs are distinguished: aqueous type-A FIs, $\mathrm{N}_{2}$-bearing type-N FIs, and $\mathrm{CO}_{2}-\mathrm{N}_{2}$-bearing type-G FIs. Type-A and type-N FIs are restricted to garnet from the Wirtbartl pegmatite field and type-G FIs entrapped in garnet samples from the Handalpe, Gressenberg, and Koralpetunnel. All three types characterize primary to pseudo-secondary inclusions arranged in single and/or cluster textures. They can vary from one-phase liquid to polyphase liquid/vapor/solid inclusions (Figure 3a-d). Polyphase FIs show high variations in liquid/vapor proportions, have an irregular shape, and are locally affected by necking-down processes. A high number of solid phases is observed in individual inclusions that occupy up to $70 \%$ of the volume of the inclusion. Type-N FIs contain solids characterized as muscovite, carbonate (rhodochrosite), rutile, and graphite. Type-A FIs comprise muscovite, rhodochrosite, apatite and graphite. Type-G FIs contain rhodochrosite, muscovite, graphite, quartz, kyanite, rutile, apatite, xenotime, and ilmenite. Consequently, the separate occurrence of primary aqueous and gas $\left(\mathrm{N}_{2}\right.$ and $\left.\mathrm{CO}_{2}-\mathrm{N}_{2}\right)$ inclusion types in magmatic garnet samples indicates entrapment of two separate fluids during the magmatic garnet growth stages. Fluid chemistry and solids were identified by Raman spectroscopy (Figure 4).

During microthermometry, type-N FIs show bubble nucleation during cooling, which homogenize to liquid at temperatures between -150.0 and $-148.3^{\circ} \mathrm{C}$. Calculations give densities from 0.43 to $0.47 \mathrm{~g} / \mathrm{cm}^{3}$ (Table 1).

Type-A FIs show apparent eutectic temperatures $\left[T_{\mathrm{e}}\right.$ (ice)] around $-60{ }^{\circ} \mathrm{C}$ and thus approximate a $\mathrm{H}_{2} \mathrm{O}-\mathrm{NaCl}-\mathrm{CaCl}_{2} \pm \mathrm{MgCl}_{2}$ fluid system. Hydrohalite final melting temperatures $\left[T_{\mathrm{m}}(\mathrm{HH})\right]$ between -38.5 and $-33.0{ }^{\circ} \mathrm{C}$ indicate a $\mathrm{CaCl}_{2}: \mathrm{NaCl}$ ratio of about $4: 1$. The final melting of ice $\left[T_{\mathrm{m}}(\mathrm{Ice})\right]$ occurs between -8.7 and $-4.1^{\circ} \mathrm{C}$. In cases, where a bubble is present, total homogenization into the liquid [ $T_{\mathrm{h}}($ tot $\left.)\right]$ occurs between 192.6 and $321.0^{\circ} \mathrm{C}$. Densities and total salinities range from 0.76 to $0.99 \mathrm{~g} / \mathrm{cm}^{3}$ and from 7.2 to 12.8 equiv. mass $\%$, respectively.

Type-G FIs with last melting temperatures $\left[T_{\mathrm{m}}\right.$ (car)] from -65.3 to $-56.6{ }^{\circ} \mathrm{C}$ indicate a large range in $\mathrm{CO}_{2} / \mathrm{N}_{2}$ proportions $\left(\mathrm{CO}_{2}\right.$ content $\left.>60 \mathrm{~mol} \%\right)$ with homogenization temperatures $\left[T_{\mathrm{h}}(\mathrm{car})\right]$ from -60.0 to $+22.0^{\circ} \mathrm{C}$. All FIs homogenize to liquid and the large range in $T_{\mathrm{h}}$ (car) indicates intense re-equilibration as a result of post-entrapment density and compositional changes. Calculated densities lie between 0.61 and $1.16 \mathrm{~g} / \mathrm{cm}^{3}$ (Table 1). 


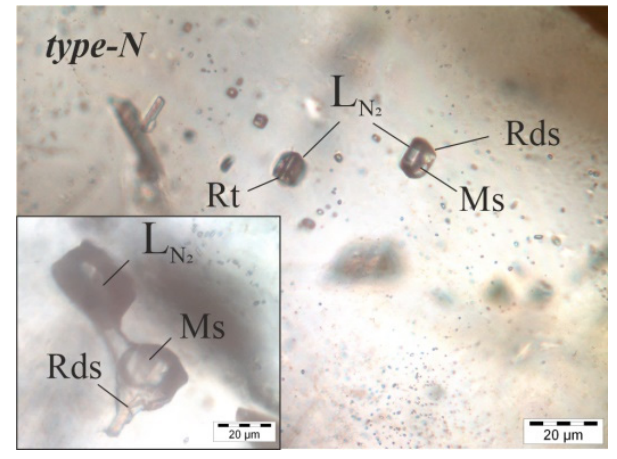

(a)

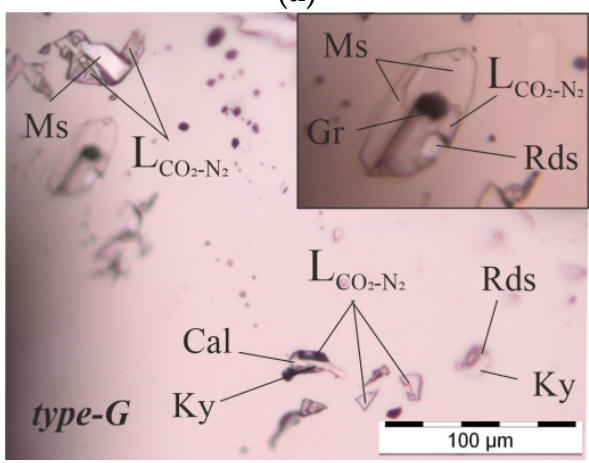

(c)

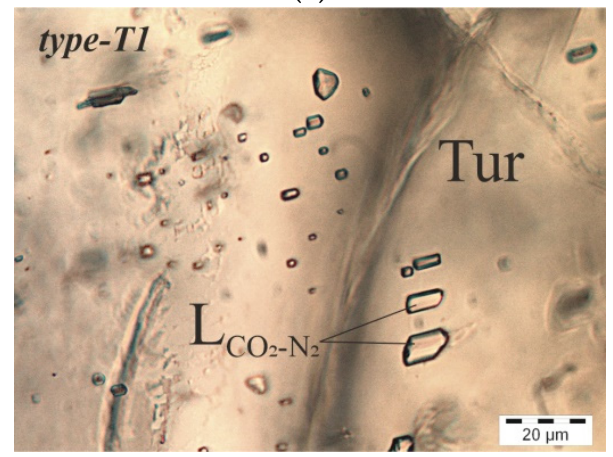

(e)

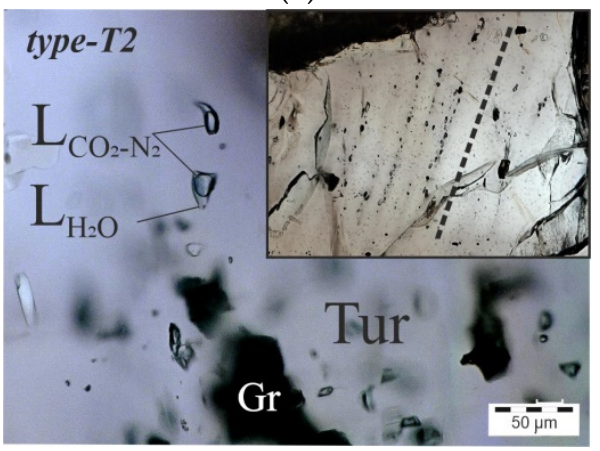

(g)

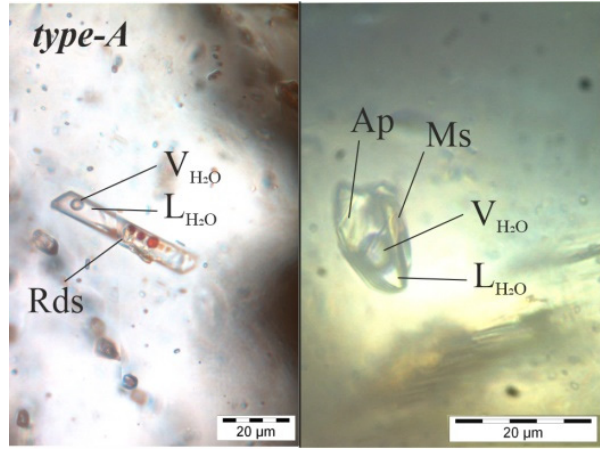

(b)

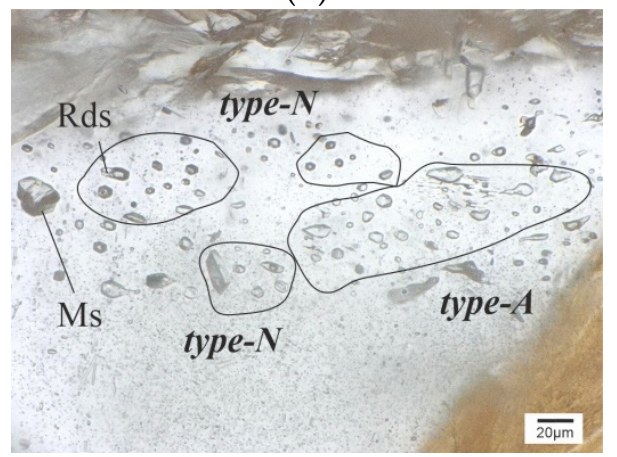

(d)

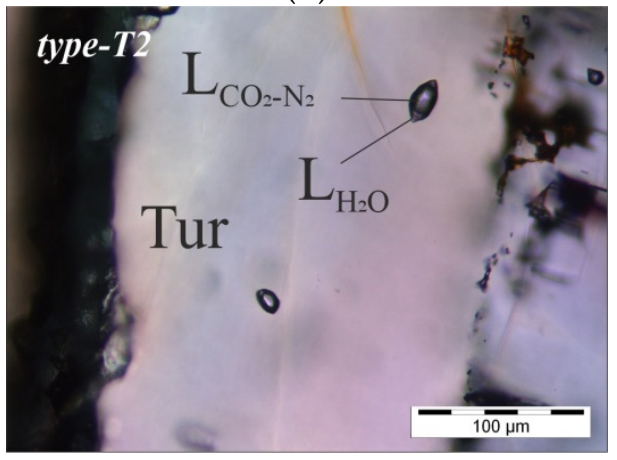

(f)

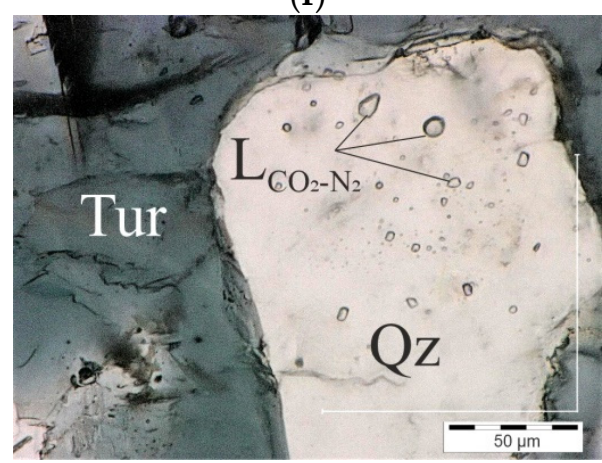

(h)

Figure 3. Cont. 


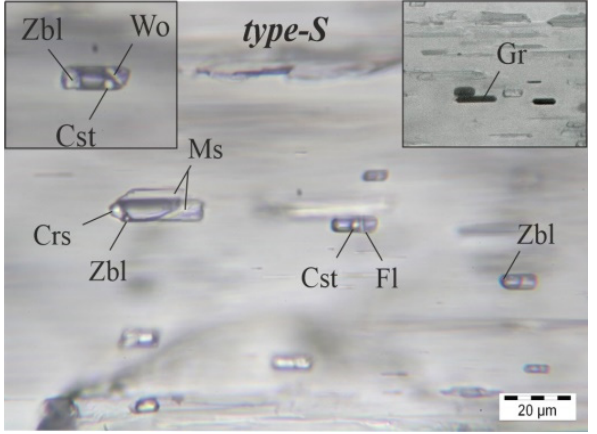

(i)

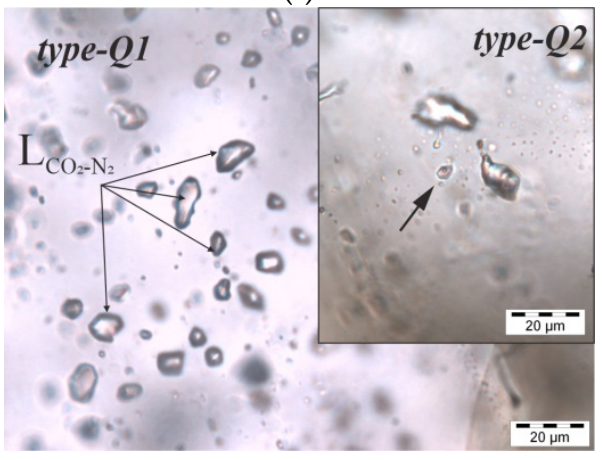

$(\mathbf{k})$

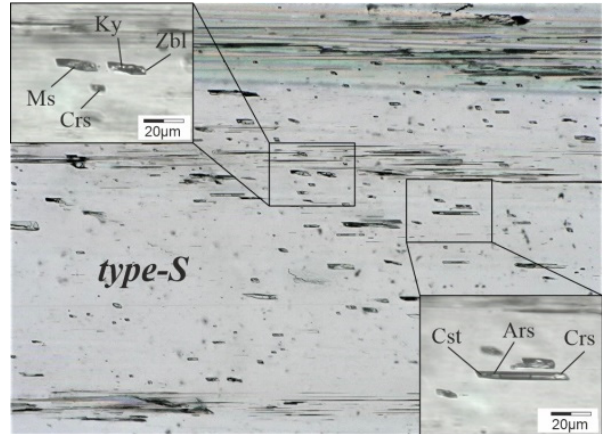

(j)

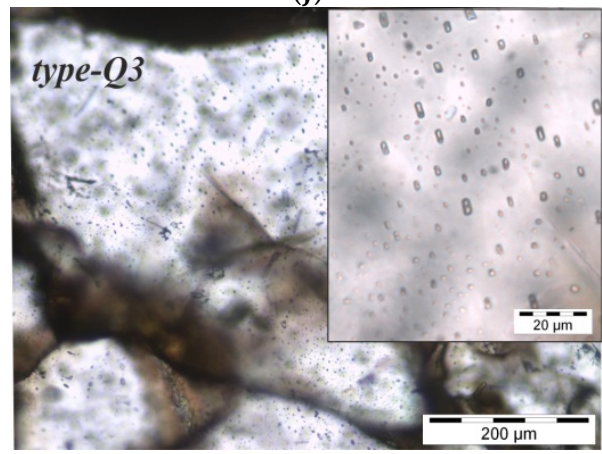

(1)

Figure 3. Fluid inclusion types. (a) Primary type-N FIs consisting of liquid $\mathrm{N}_{2}\left(\mathrm{~L}_{\mathrm{N} 2}\right)$ and solids ( $\mathrm{Rt}=$ rutile, $\mathrm{Ms}=$ muscovite, and Rds = rhodochrosite). Detail: necking-down of type-N inclusion results into two separate FIs that are connected by a thin tube. (b) Primary type-A aqueous inclusions containing Rds (left image); apatite (Ap) and Ms (right image) $\left(\mathrm{L}_{\mathrm{H} 2 \mathrm{O}}=\right.$ liquid $\mathrm{H}_{2} \mathrm{O}, \mathrm{V}_{\mathrm{H} 2 \mathrm{O}}=$ vapor $\left.\mathrm{H}_{2} \mathrm{O}\right)$. (c) Type-G FIs consisting of liquid $\mathrm{CO}_{2}-\mathrm{N}_{2}\left(\mathrm{~L}_{\mathrm{CO} 2-\mathrm{N} 2}\right)$ and various solids (Ms, Rds, Cal = calcite, $\mathrm{Ky}=$ kyanite). Detail shows Type-G FI and solids Ms, Rds and Gr (graphite). (d) Plane of type-N and type-A FIs nearby a muscovite solid inclusion. FIs have an irregular shape and show variations in volume proportions because of the presence or absence of solids (type-N). Type-A FIs show necking and consist of one-phase liquid. (a,b,d) from samples WB01/02 and (c) from sample Kor_3. (e) Type-T1 FIs in tourmaline from sample W05. FIs are primary, one-phase liquid and show negative crystal shape. (f) Type-T2 FIs in tourmaline from sample W04. FIs are two-phase and entrapped near graphite-bearing cracks. (g) Type-T2 FIs in tourmaline from sample W04. FIs are necked and entrapped near graphite inclusions. Insert shows trail orientation (dashed line) of secondary graphite-bearing type-T2 FIs towards the edge of the tourmaline crystal. (h) Tourmaline poikiloblast from sample WB01. $\mathrm{CO}_{2}-\mathrm{N}_{2}$-bearing FIs (one phase liquid) with well-preserved rounded shapes entrapped in enclosed quartz aggregates. (i) Type-S FIs from spodumene host of sample W08. FIs are polyphase and entrapped parallel to cleavage planes of the host. FIs in detailed images have a size of ca. $20 \mu \mathrm{m}$. (j) Polyphase Type-S FIs in spodumene host from sample Klem_1. (k) Type-Q1/Q2 FIs

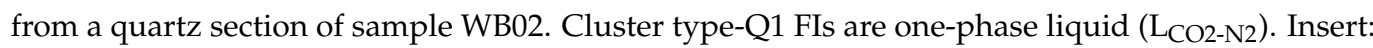
necked large $\mathrm{CO}_{2}-\mathrm{N}_{2}$ FIs nearby a small two-phase aqueous FI (black arrow; type-Q2). (1) Cluster of small type-Q3 FIs in recrystallized quartz, crossing grain boundaries. Insert shows that FIs are oriented, have constant liquid/vapor proportion, and a common shape. 


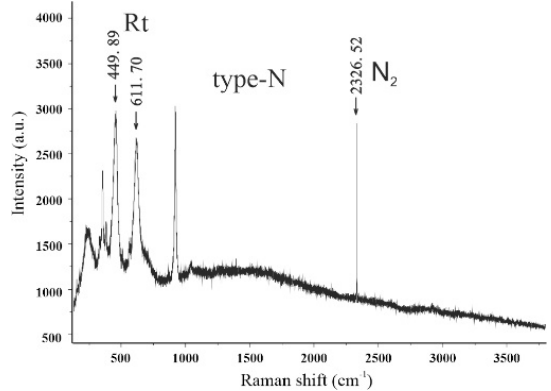

(a)

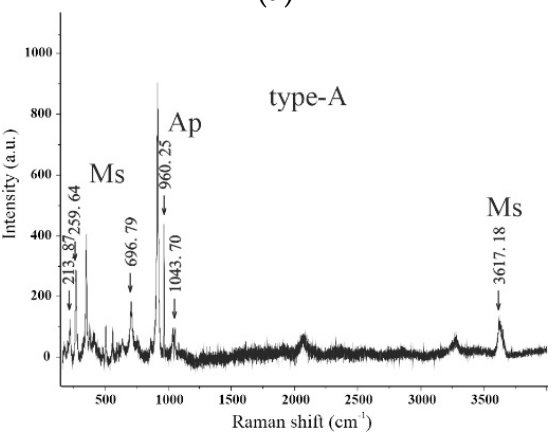

(c)

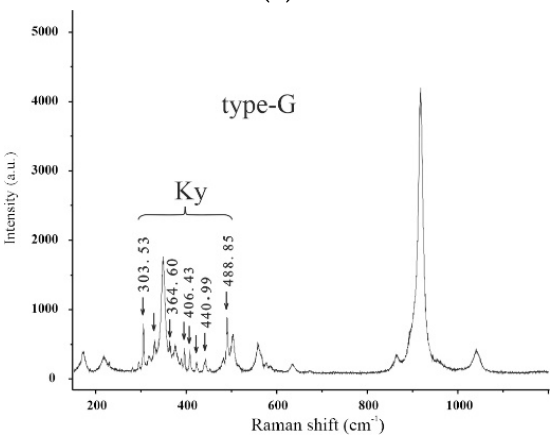

(e)

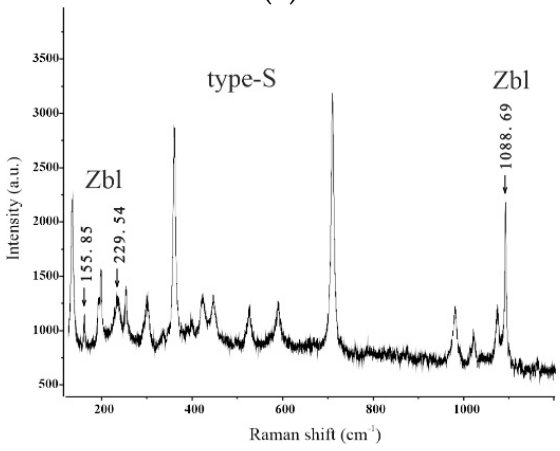

(g)

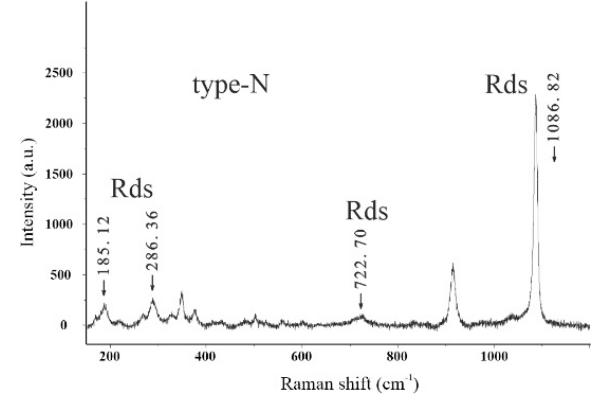

(b)

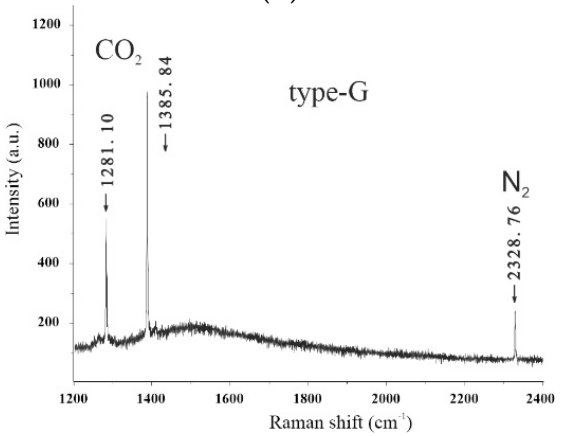

(d)

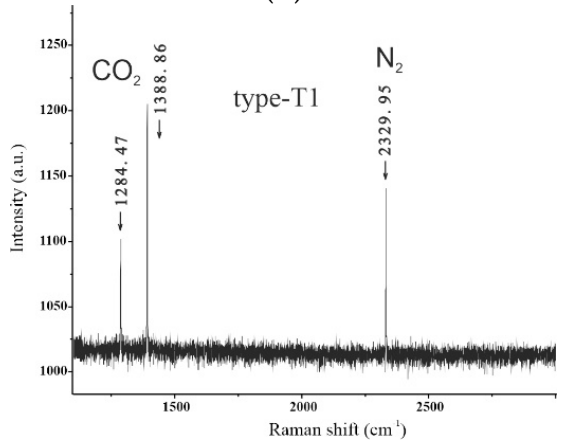

(f)

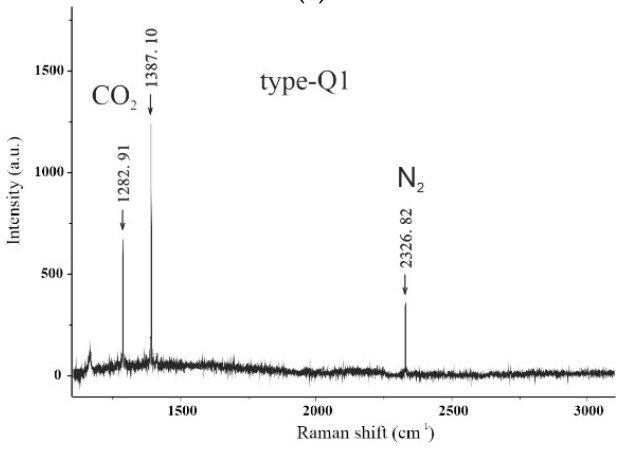

(h)

Figure 4. Raman spectra of selected FI-types. Peaks without numbers are related to the host minerals garnet (a-e), tourmaline (f), spodumene (g), and quartz (h). (a) Type-N inclusions characterized by a dominant $\mathrm{N}_{2}\left(2326.52 \mathrm{~cm}^{-1}\right)$ peak. Spectra with numbered peaks correspond to rutile as an enclosed mineral phase. (b) Type-N inclusion containing rhodochrosite as solid-phase inclusion. (c) Type-A inclusion containing apatite and muscovite solid phases. (d) Type-G inclusion consisting of $\mathrm{CO}_{2}$ (1281.10 and $\left.1385.84 \mathrm{~cm}^{-1}\right)$ and $\mathrm{N}_{2}\left(2328.76 \mathrm{~cm}^{-1}\right)$. (e) Type-G inclusion containing a kyanite solid phase. (f) Spectra of type-T1 inclusion in tourmaline consisting of $\mathrm{CO}_{2}\left(1284.47\right.$ and $\left.1388.86 \mathrm{~cm}^{-1}\right)$ and $\mathrm{N}_{2}\left(2329.95 \mathrm{~cm}^{-1}\right)$. (g) Type-S inclusion in spodumene containing a zabuyelite solid phase. (h) Spectra of type-Q1 inclusion consisting of $\mathrm{CO}_{2}\left(1282.91\right.$ and $\left.1387.10 \mathrm{~cm}^{-1}\right)$ and $\mathrm{N}_{2}\left(2326.82 \mathrm{~cm}^{-1}\right)$. 
The observed large range in homogenization, as well as high variations in shape and solid content of the inclusions, suggest intense post-entrapment modification so that all inclusion types in garnets (N, A, and $\mathrm{G}$ ) are unsuitable for the estimation of pressures and temperatures of garnet crystallization.

\subsubsection{Fluid Inclusions in Tourmaline (Type-T1 and Type-T2)}

FIs from tourmaline have been studied at locations Handalpe (W04/W05) and Gressenberg (W06). Two major types of primary inclusions in tourmaline crystals have been observed. Primary type-T1 is characterized by one-phase (L) $\mathrm{CO}_{2}-\mathrm{N}_{2}$ chemistry and type-T2 with two-phase (L-L) $\mathrm{CO}_{2}-\mathrm{N}_{2} \pm \mathrm{CH}_{4}-\mathrm{H}_{2} \mathrm{O}$ chemistry (Figure 3e,f). Type-T1 has a negative crystal shape and is the dominant inclusion type (ca. $90 \%$ incidence) whereas subordinately (ca. 10\% incidence) preserved type-T2 entrapped nearby graphite bearing cracks showing locally necking-down characteristics with some additional $\mathrm{CH}_{4}$ content (Figure $3 \mathrm{~g}$ ). Hence type-T2 FIs are attributed as pseudo-secondary and/or secondary. No solid inclusions have been found in type-T1 and type-T2 FIs. Raman spectroscopy for type-T1 is given in Figure $4 \mathrm{f}$.

Microthermometry of type-T1 FIs shows bubble appearance during cooling. The last melting of carbonic liquid $\left[T_{\mathrm{m}}(\mathrm{car})\right]$ between -60.0 and $-58.7^{\circ} \mathrm{C}$ is indicative for the additional nitrogen component to $\mathrm{CO}_{2}$ liquid. The $\mathrm{CO}_{2}$ content lies between 0.71 and $0.80 \mathrm{~mol} \%$. The lowest homogenization of carbonic vapor $\left[T_{\mathrm{h}}(\mathrm{car})\right]$ to the liquid ranges from -54.9 to $-32.8^{\circ} \mathrm{C}$ and results in densities from 0.80 to $0.85 \mathrm{~g} / \mathrm{cm}^{3}$ (Table 1 ).

Type-T2 FIs show $\left[T_{\mathrm{m}}(\mathrm{car})\right]$ between -61.8 and $-58.3^{\circ} \mathrm{C}$ and homogenization $\left[T_{\mathrm{h}}(\mathrm{car})\right]$ to liquid varies from -47.4 to $7.7^{\circ} \mathrm{C}$. This large range in $T_{\mathrm{h}}(\mathrm{car})$ indicates the postentrapment character of this inclusion type. The aqueous phase gives apparent eutectic temperatures $\left[\mathrm{T}_{\mathrm{e}}(\mathrm{ice})\right]$ from -54.2 to $-46.0^{\circ} \mathrm{C}$, indicative for a $\mathrm{H}_{2} \mathrm{O}-\mathrm{NaCl}-\mathrm{CaCl}_{2} \pm \mathrm{MgCl}_{2}$ fluid chemistry. Last melting of hydrohalite $\left[T_{\mathrm{m}}(\mathrm{HH})\right]$ between -27.2 and $-23.8^{\circ} \mathrm{C}$ points to a $\mathrm{NaCl} /\left(\mathrm{NaCl}+\mathrm{CaCl}_{2}\right)$ ratio of ca. 0.7 . The last melting of ice from -4.5 to $-3.1^{\circ} \mathrm{C}$ and observed clatrate melting $\left[T_{\mathrm{m}}(\mathrm{Cla})\right]$ of $>8.5^{\circ} \mathrm{C}$ indicate a low total salinity of about 5 equiv. mass $\%$ of the aqueous fluid component. The lowest homogenization temperatures of carbonic vapor $\left[T_{\mathrm{h}}\right.$ (car)] to the liquid at $-47.4{ }^{\circ} \mathrm{C}$ come from sample W04 (Figure 3f) and give densities of $0.87 \mathrm{~g} / \mathrm{cm}^{3}$, that are slightly higher compared to calculated densities of type-T1 FIs. Total homogenization $\left[T_{\mathrm{h}}(\right.$ tot $\left.)\right]$ to one-phase aqueous liquid occurred between 215.1 and $294.5^{\circ} \mathrm{C}$.

Some tourmaline grains have poikiloblastic character. Their enclosed quartz grains contain FIs with well-preserved rounded shapes (Figure 3h). Raman spectra clearly indicate $\mathrm{CO}_{2}-\mathrm{N}_{2}$ chemistry. They are therefore attributed to inclusions that have been entrapped coevally to type-T1 FIs in tourmaline host.

\subsubsection{Fluid Inclusions in Spodumene (Type-S)}

FIs in spodumene crystals from Brandrücken (W07/08) and Klementkogel (Klem_1) pegmatite fields can be assigned to one inclusion type-S, consisting of $\mathrm{CO}_{2}-\mathrm{N}_{2}-\mathrm{H}_{2} \mathrm{O}-\mathrm{NaCl}-$ $\mathrm{CaCl}_{2} \pm \mathrm{MgCl}_{2}$ fluid chemistry. Type-S FIs are polyphase, have a size from 5 to $30 \mu \mathrm{m}$ at Brandrücken area, and reach a large size of up to $150 \mu \mathrm{m}$ at Klementkogel. All FIs are tube-like, elongated and necked in shape, and enriched in solids (Figure 3i,j). Solids vary from quartz (cristobalite), carbonate (zabuyelite), muscovite, cassiterite, wollastonite, and graphite. Kyanite, arsenolite, fluorite, sphalerite, albite, and zircon have been additionally detected in FIs from the Klementkogel (Figure 3j). All solids were identified by Raman spectroscopy (Figure 4g).

Microthermometry of type-S inclusions from the Brandrücken area give $T_{\mathrm{m}}$ (car) between -58.0 and $-57.5^{\circ} \mathrm{C}$ and $T_{\mathrm{h}}$ (car) to liquid from 0.3 to $17.0^{\circ} \mathrm{C}$. Eutectic temperatures of the aqueous phase range from -55.2 to $-53.6{ }^{\circ} \mathrm{C}$, indicative of a complex $\mathrm{H}_{2} \mathrm{O}-\mathrm{NaCl}-\mathrm{CaCl}_{2}$ $\pm \mathrm{MgCl}_{2}$ fluid chemistry. The last melting of hydrohalite $\left[T_{\mathrm{m}}(\mathrm{HH})\right]$ and ice $\left[T_{\mathrm{m}}(\mathrm{ice})\right]$ lie between -28.0 and $-23.2{ }^{\circ} \mathrm{C}$ as well as -7.7 and $-4.2{ }^{\circ} \mathrm{C}$, respectively. $\left[T_{\mathrm{m}}(\mathrm{HH})\right]$ indicates a $\mathrm{NaCl} /\left(\mathrm{NaCl}+\mathrm{CaCl}_{2}\right)$ ratio of ca. 0.7 . Clathrate melting yields temperatures from 7.9 to 
$13.2^{\circ} \mathrm{C} . T_{\mathrm{m}}(\mathrm{Cla})$ together with $T_{\mathrm{m}}$ (ice) indicates total salinities between 7.3 and 11.6 equiv. mass \%. Total homogenization to one-phase aqueous liquid occurred from 302.1 to $583.0^{\circ} \mathrm{C}$ (Table 1).

Type-S inclusions at Klementkogel show comparable microthermometry data to the Brandrücken area, however, FIs tend to homogenize to liquid and to vapor near ca. $20{ }^{\circ} \mathrm{C}$. FIs may therefore contain a vapor bubble at room temperature conditions. Slightly lower total salinities from 3.8 to 9.6 mass $\%$ are calculated. Total homogenization occurred between 255.8 and $311.7^{\circ} \mathrm{C}\left(\mathrm{Spd}^{*}\right.$ in Table 1$)$.

The large range in calculated densities from 0.72 to $1.11 \mathrm{~g} / \mathrm{cm}^{3}$ from Brandrücken spodumene samples compared to 0.68 to $0.89 \mathrm{~g} / \mathrm{cm}^{3}$ from Klementkogel as well as their large number of solid phases, support post-entrapment character (i.e., necking down combined with in-situ fluid/host reactions, see Discussion section) and type-S FIs are therefore unsuitable for PT estimates of spodumene crystallization.

\subsubsection{Fluid Inclusions in the Recrystallized Quartz Matrix (Type-Q1, Type-Q2, and Type-Q3)}

FIs in the recrystallized quartz matrix have been studied in samples of the Wirtbartl pegmatite field (WB01/02). Based on chemistry and textures, FIs are distinguished into three major inclusion types. Within quartz grains, clusters of the early type-Q1 consisting of $\mathrm{CO}_{2}-\mathrm{N}_{2}$ chemistry with one phase (L) at room temperature are preserved (Figures $3 \mathrm{k}$ and $4 \mathrm{~h}$ ). The chemistry of type-Q1 is comparable to FIs in enclosed quartz grains of tourmaline, but FIs show here intense post-entrapment modifications resulting into necking and density re-equilibration. Besides type-Q1, decrepitation as well as necking-down textures, suggesting former large $\mathrm{CO}_{2}-\mathrm{N}_{2}-\mathrm{H}_{2} \mathrm{O}$-rich FIs, occur (type-Q2). They consist of small two-phase aqueous FIs that occasionally surround large $\mathrm{CO}_{2}-\mathrm{N}_{2}-$ bearing FIs (insert in Figure 3k). From a textural point of view, it is unclear if large $\mathrm{CO}_{2}-\mathrm{N}_{2}$ FIs correspond to former type-Q1 FIs. A younger generation of small two-phase homogenously entrapped FIs, arranged as clusters and planes crossing grain boundaries, define type-Q3 FIs (Figure 31). Type-Q3 FIs are clearly oriented and have a common shape. They are restricted to areas where quartz grains show recrystallization.

Microthermometry of type-Q1 show last melting temperatures $\left[T_{\mathrm{m}}(\mathrm{car})\right]$ between -60.0 and $-59.2^{\circ} \mathrm{C}$, supporting the additional nitrogen component to the $\mathrm{CO}_{2}$-rich fluid. A wide range in homogenization temperatures $\left[T_{\mathrm{h}}(\mathrm{car})\right]$ to the liquid between -25.3 and $-5.7{ }^{\circ} \mathrm{C}$ and to vapor between -41.0 and $-31.1^{\circ} \mathrm{C}$ supports intense post-entrapment modification and re-equilibration. This makes type-Q1 inclusions unsuitable for pressure and temperature estimates for quartz crystallization. Type-Q2 FIs show $T_{\mathrm{m}}$ (car) around $-59.6{ }^{\circ} \mathrm{C}$ and homogenization to the liquid between -23.2 and $-17.2\left[T_{\mathrm{h}}(\mathrm{car})\right]$. Surrounding small aqueous two-phase $(\mathrm{L}, \mathrm{V})$ FIs give a wide range in $T_{\mathrm{h}}$ (total) between 130.5 and $206.0^{\circ} \mathrm{C}$. On the basis of $T_{\mathrm{e}}($ ice $)$ between -42.2 and $-48.4^{\circ} \mathrm{C}$, FIs consist of $\mathrm{H}_{2} \mathrm{O}-\mathrm{NaCl}-$ $\mathrm{CaCl}_{2} \pm \mathrm{MgCl}_{2}$ fluid chemistry. $T_{\mathrm{m}}(\mathrm{HH})$ from -33.0 to $-29.2{ }^{\circ} \mathrm{C}$ indicate a $\mathrm{NaCl} /(\mathrm{NaCl}$ $\left.+\mathrm{CaCl}_{2}\right)$ ratio of ca. 0.4 . Last melting of ice $\left[T_{\mathrm{m}}(\mathrm{ice})\right]$ between -11.2 and $-9.0{ }^{\circ} \mathrm{C}$ gives a total salinity range from 13.0 to 15.0 equiv. mass\%. Due to the decrepitation character, densities have not been calculated (Table 1).

Type-Q3 characterized by eutectic temperatures $\left[T_{\mathrm{e}}(\mathrm{ice})\right]$ between -60.0 and $-40.0{ }^{\circ} \mathrm{C}$ as an $\mathrm{H}_{2} \mathrm{O}-\mathrm{NaCl}-\mathrm{CaCl}_{2} \pm \mathrm{MgCl}_{2}$ fluid system shows total homogenization temperatures $\left[T_{\mathrm{h}}\right.$ (tot) $]$ to the liquid between 125.5 and $176.2^{\circ} \mathrm{C}$. Calculated densities range from 1.02 to $1.10 \mathrm{~g} / \mathrm{cm}^{3}$. Salinities based on $T_{\mathrm{m}}$ (ice) between -19.0 and $-11.0^{\circ} \mathrm{C}$ range from 15.0 to 20.2 equiv. mass \%. Based on $T_{\mathrm{m}}(\mathrm{HH})$ between -37.8 and $-29.3{ }^{\circ} \mathrm{C}$, the $\mathrm{NaCl} /(\mathrm{NaCl}+$ $\mathrm{CaCl}_{2}$ ) ratio is about 0.3 .

\subsection{Solid Mineral Inclusion Study}

Mineral inclusions found in magmatic garnet grains are apatite, quartz, albite, kyanite, and muscovite. On the subsurface level, solid mineral inclusions in open cavities, suspected to be FIs, have been studied by using two different electron microprobes (see Section 4). Polyphase mineral inclusions consist of muscovite-quartz, and muscovite-kyanite assem- 
blages (Figure 5a). In spodumene crystals, solids in tubular-shaped type-S FIs consist of muscovite, zabuyelite, cassiterite, and rutile (Figure $5 b, c)$. All inclusions have additionally been analyzed by Raman spectroscopy.
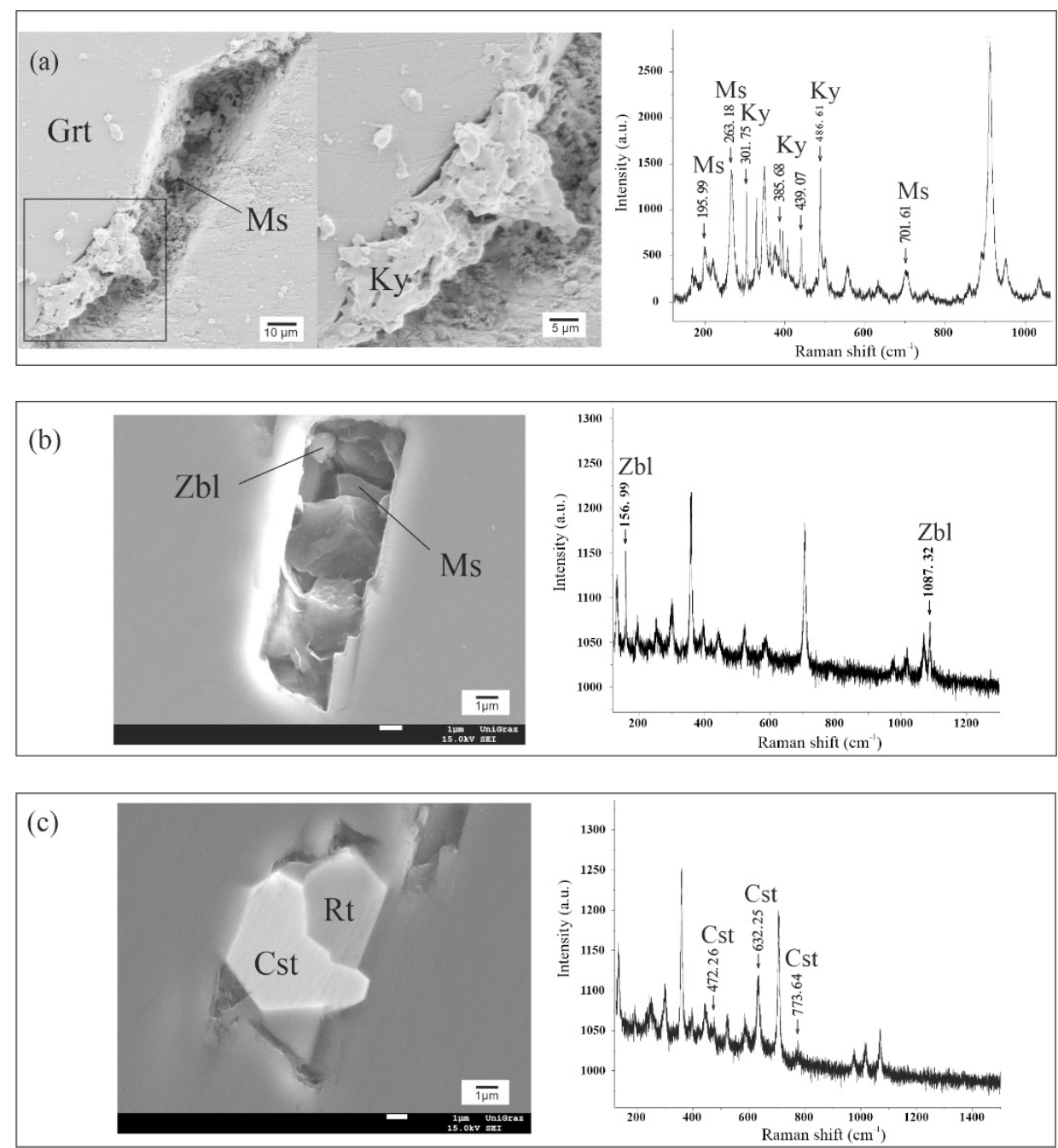

Figure 5. Electron microprobe images of subsurface cavities from (a) garnet host (sample WB01) and $(\mathbf{b}, \mathbf{c})$ spodumene host (sample W08). Representative Raman spectra are shown on the right side.

\subsection{Major Element Chemistry of Magmatic Garnet Domains}

In order to characterize the chemistry of garnet domains from garnet samples WB01/02 where types-A and $\mathrm{N}$ occur, major element zoning patterns, as well as point measurements, have been performed. Studied garnet fragments are mainly composed of a spessartinealmandine solid solution and therefore comparable to magmatic garnets reported by Habler et al. [26]. They show well preserved homogeneous end-member garnet patterns $(\mathrm{XFe}, \mathrm{XMn}, \mathrm{XMg}, \mathrm{XCa}$ ) that are characterized by relatively low constant values of $\mathrm{XCa}$ between 0.015 and 0.024 from the cores towards the outermost rim areas (Figure 6a). Point measurements in selected garnet domains close to the studied FIs plot in the same range and indicate FIs that were entrapped in magmatic garnet domains (right diagram in Figure 6a). For comparison, Figure 6 b shows a magmatic garnet, which contains a small metamorphic rim zone that is characterized by increasing XCa and decreasing XFe and XMn contents. The trend in metamorphic overgrowth is after Habler et al. [26]. 


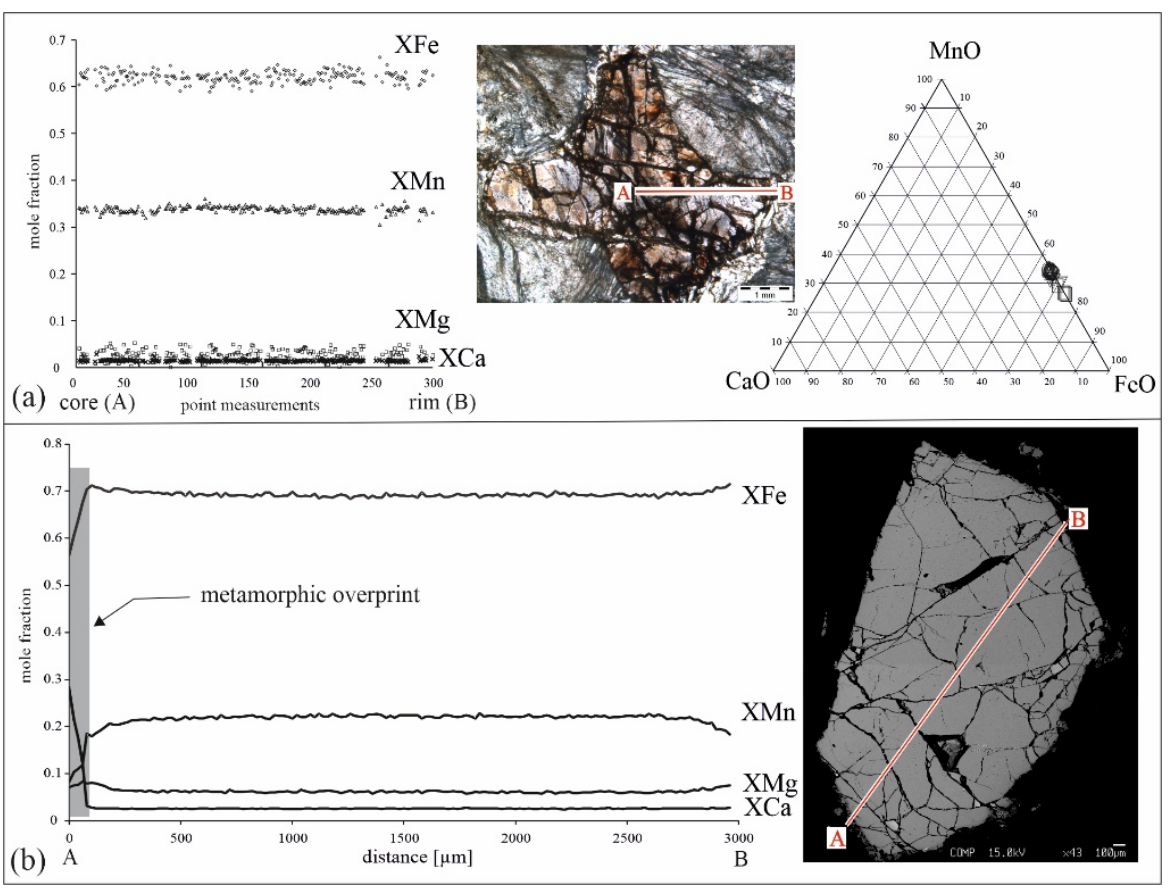

Figure 6. (a) Major element composition of a magmatic garnet fragment containing investigated FIs of sample WB01. Left: core (A) to rim (B) major element line profile with a length of ca. $3 \mathrm{~mm}$, corresponding to 300-point analyses. No significant increase in XCa between core and rim exists. Right: major element point measurements in garnet close to domains of studied FI types- $\mathrm{A}$ and $\mathrm{N}$ in WB01/02. Symbols correspond to different fluid inclusion locations in the studied garnet fragments. (b) Major element composition of a big-sized magmatic garnet. Only the outermost $70 \mu \mathrm{m}$ have been affected by a metamorphic overprint. Metamorphic overprint is characterized by an increasing trend of XCa (lowermost line) and decreasing trends in XFe and XMn (garnet from sample Kor_3).

\section{Discussion}

\subsection{Origin of Fluids and Their Post-Entrapment Modification \\ 6.1.1. Fluid Unmixing during Garnet Crystallization}

Studied FIs in garnet are characterized as texturally primary. This is the case for aqueous (type-A) FIs, $\mathrm{N}_{2}$ (type-N), and $\mathrm{CO}_{2}-\mathrm{N}_{2}$ (type-G) FIs. Solid mineral inclusions in these types are characterized as quartz, muscovite, carbonate (rhodochrosite), kyanite, rutile, apatite, and graphite and can be interpreted as (a) daughter minerals crystallized from the fluid, (b) accidentally trapped inclusions (e.g., kyanite, rutile, apatite) and/or (c) as a probable result of in-situ mineral reactions between the fluid and the garnet host (e.g., Mn-bearing carbonates like rhodochrosite). The solid growth of rhodochrosite at the inclusion wall can be examined in Figure $3 c$ (detailed image), where no clear transition between the solid inclusion and its host mineral is visible. Mineral reactions forming solids at the inclusion walls as an effect of reaction with the host are also described in mantle-derived olivine or in spodumene host crystals [46-48].

However, the remaining nitrogen content and the presence of carbonate solids associated with type-N FIs may originate from partial melting of the granitic melt with the host rock, particularly by fluid-mineral exchange reactions that deal with $\mathrm{NH}_{4}{ }^{+}$bearing mica of metasedimentary gneisses [49]. Additionally, the frequent occurrence of primary type-G FIs in magmatic garnet domains suggests fluid modification by decarbonation, leaving behind the present nitrogen fluid and carbonate \pm graphite solids in type-N FIs. Therefore, it is proposed that the $\mathrm{CO}_{2}-\mathrm{N}_{2}$-rich fluid defines the high-grade metamorphic fluid that dominated during an early pegmatite forming stage where anatectic melt crystallizes to form pegmatites (stage 1 in Figure 7). Together with type-A FIs, two unmixed $\mathrm{H}_{2} \mathrm{O}$ and $\mathrm{CO}_{2}-\mathrm{N}_{2}$-rich fluids entrapped during garnet crystallization. This is based on the large P-T 
region of immiscibility for fluids under high-grade metamorphic conditions that led to the simultaneous trapping of coexisting carbonic-nitrogen and aqueous saline FIs [50]. The low-saline aqueous type-A FIs are interpreted as the unmixed magmatic fluid component.

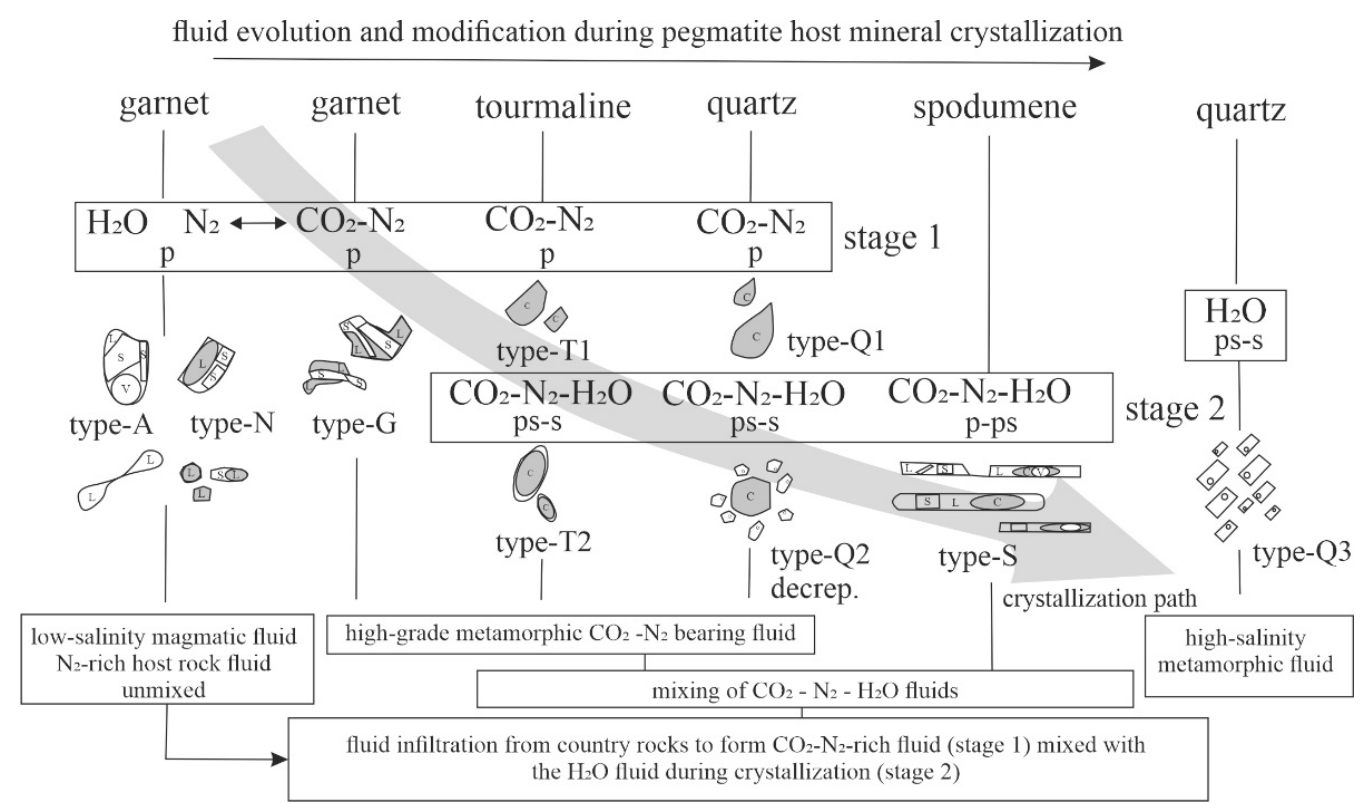

Figure 7. Origin and relationship between different fluids entrapped in studied host minerals.

\subsubsection{Magmatic-Metamorphic Fluid Mixing during Tourmaline and Quartz Crystallization}

Two major types of FIs are entrapped in tourmaline, whereas type-T1 with $\mathrm{CO}_{2}-\mathrm{N}_{2}$ chemistry dominates up to $90 \%$ and type-T2 with $\mathrm{CO}_{2}-\mathrm{N}_{2}-\mathrm{H}_{2} \mathrm{O}$ chemistry represents only $10 \%$ of the inclusions. In conjunction with fluid chemistry, the primary textural occurrence, as well as the negative (host-) crystal shape of type-T1 FIs, suggest that type-T1 FIs are coeval to type-G FIs, characterizing the predominating metamorphic fluid which entrapped during early tourmaline growth. No aqueous FIs like type-A in garnet have been found in tourmaline. Quartz inclusions in tourmaline porphyroblasts of the Wirtbartl pegmatite field contain $\mathrm{CO}_{2}-\mathrm{N}_{2}$ FIs supporting type-T1 as the major fluid type during growth of tourmaline (Figure $3 \mathrm{~h}$ ). The rare presence of type-T2 FIs in tourmaline indicates that during tourmaline growth, the $\mathrm{CO}_{2}-\mathrm{N}_{2}$ high-grade metamorphic fluid mixed with the remaining magmatic aqueous fluid along the solvus of the $\mathrm{H}_{2} \mathrm{O}-\mathrm{CO}_{2}-\mathrm{N}_{2}$ system (fluid stage 2; Figure 7). Type-T2 FIs entrapped near fractures and show locally necking-down, indicating that these FIs have a pseudo-secondary to secondary character (Figure 3f,g).

In samples of the Wirtbartl area, quartz grains reflect comparable inclusion types to tourmaline indicated by the presence of early primary type-Q1 FIs of $\mathrm{CO}_{2}-\mathrm{N}_{2}$ chemistry together with potential $\mathrm{CO}_{2}-\mathrm{N}_{2}-\mathrm{H}_{2} \mathrm{O}$ FIs (type-Q2). However, both types (Q1 and Q2) underwent intense post-entrapment modification during cooling and/or subsequent Cretaceous metamorphism (Figure 7).

\subsubsection{Mixed Fluid during Spodumene Crystallization}

Spodumene crystals in all study areas host numerous type-S FIs of low-saline $\mathrm{CO}_{2-}$ $\mathrm{N}_{2}-\mathrm{H}_{2} \mathrm{O}$-rich chemistry that are attributed to one fluid generation. Fluid composition is comparable to type-T2 in tourmaline, however, FIs in spodumene show a primary to pseudo-secondary character. This is due to the incursion and interaction of this fluid within the spodumene host cleavage (i.e., inclusion orientation parallel to the crystallographic c-axis), producing planar arrays of numerous crystal-rich type-S FIs and suggesting a high solubility of the spodumene host along with the crystallographic orientation in the fluid $[47,48]$. The majority of the spodumene-hosted FIs exhibit a euhedral negative crystal shape, which was affected by post-entrapment modification processes, like necking-down 
(Figure $3 \mathrm{i}, \mathrm{j}$ ). This process is not only proposed for minerals of high cleavage like pyroxenes, necking-down occurs also in minerals without or of poor cleavage, like quartz [51] or danburite [52], respectively.

The variable number of solid phases occupies up to $70 \%$ of the volume of the inclusion. Most type-S FIs contain quartz and/or cristobalite, zabuyelite and/or calcite, as well as hydrated phyllosilicates (e.g., muscovite), within a low-saline aqueous carbonic fluid. Like in garnet, observed solid phases were either accidentally trapped (cassiterite, rutile, sphalerite, arsenolite, zircon, fluorite, columbite, and albite) or crystallized by the fluid. However, as discussed in Anderson et al. [47], they may be a product of fluid-host-interaction. Solids like quartz and/or cristobalite, carbonates (zabuyelite), and muscovite are assumed as having formed due to in-situ mineral reactions of the fluid with the spodumene host. Additionally, reduction of the carbonic (and diffusion of the aqueous) phase also formed graphite inside the inclusions (insert in Figure 3i).

Thus, in-situ reactions, involving an early $\mathrm{H}_{2} \mathrm{O}-\mathrm{CO}_{2}$-rich fluid together with spodumene host, formed carbonates (calcite, zabuyelite), hydrous silicates (muscovite), as well as $\mathrm{Ca}$ - and/or aluminosilicates (wollastonite, kyanite) within the studied type-S FIs. This low-saline $\mathrm{CO}_{2}-\mathrm{N}_{2}-\mathrm{H}_{2} \mathrm{O}$-rich fluid was present during spodumene-crystallization, but FIs do not represent the original fluid properties (density and composition) and are therefore not representative for P-T estimates of spodumene crystallization. Taking under consideration the volumetric amount of each mineral, solids inside type-S FIs could be produced by the following reaction:

$6 \mathrm{LiAlSi}_{3} \mathrm{O}_{6}+2 \mathrm{H}_{2} \mathrm{O}+12 \mathrm{CO}_{2}+3 \mathrm{Ca}^{2+}+4 \mathrm{~F}^{-}+2 \mathrm{~K}^{+}=\mathrm{CaCO}_{3}+3 \mathrm{Li}_{2} \mathrm{CO}_{3}+2 \mathrm{KAl}_{2}\left[\mathrm{Si}_{3} \mathrm{AlO}_{10}\right](\mathrm{OH}, \mathrm{F})_{2}+10 \mathrm{SiO}_{2}+2 \mathrm{CaSiO}_{3}+8 \mathrm{C}$

This complex in-situ reaction (1) needs additional calcium, potassium, and fluorine for balancing and presumes a high number of solids observed in the inclusions. It is therefore not representative for a single type-S inclusion but rather exemplary for the high variability of solids that can be expected predating necking-down processes which separate the number of solids on individual inclusions [51].

\subsection{Permian Fluid Evolution during Solidification of the Granitic Melt}

The distribution of fluid types is summarized in Table 1 and complemented in Figure 7. All primary aqueous low-saline inclusion types in garnet are considered as one generation of type-A inclusions. $\mathrm{CO}_{2}-\mathrm{N}_{2}$-bearing FIs in garnet (type-G), in tourmaline (type-T1), and in quartz (type-Q1) can be combined to one fluid stage (fluid stage 1) of early entrapped primary inclusions. Primary type-N FIs are attributed to a modified type-G.

Type-A and type-N FIs are only preserved in garnet samples WB01/02 of the Wirtbartl pegmatite field-all other pegmatite samples do not exhibit these fluid types. However, their textural presence as primary unequivocally suggests the presence of a low-saline aqueous fluid, unmixed with a $\mathrm{N}_{2}\left( \pm \mathrm{CO}_{2}\right)$ fluid that formed in equilibrium with $\mathrm{NH}_{4}$ containing micas and/or feldspars in the pegmatite host rocks $[15,23]$. These two separate fluids have to be present during magmatic garnet crystallization at a P-T range above the solvus curve of the $\mathrm{H}_{2} \mathrm{O}-\mathrm{CO}_{2}-\mathrm{N}_{2}$ system. While the mobile aqueous fluid content decreases during pegmatite melt fractionation, probably during crystallization of hydrous silicates, the remaining $\mathrm{CO}_{2}-\mathrm{N}_{2}$ fluid dominated during early crystallization stages of tourmaline and quartz, indicating a metasomatic/metamorphic process of the solidifying granitic melt with the metasedimentary host-rocks. This led to mixtures of fluids and formed a $\mathrm{CO}_{2}-\mathrm{N}_{2}-\mathrm{H}_{2} \mathrm{O}$-rich fluid across the solvus of the aqueous and the carbonic fluids [50]. This mixture entrapped in tourmaline and quartz as pseudo-secondary inclusions and as primary inclusions in spodumene crystals, indicating spodumene crystallization during a late, probably more fractionated crystallization stage of the pegmatites (stage 2 in Figure 7). Decrepitation of pseudo-secondary type-Q2 inclusions in quartz and necking-down processes during entrapment of type-S FIs in spodumene as well as in garnet and tourmaline is well documented. 
Aqueous type-Q3 higher-saline pseudo-secondary to secondary FIs occur only in recrystallized matrix quartz aggregates and are therefore assigned to a post-pegmatite crystallization stage, probably related to recrystallization of quartz during Eoalpine deformation and metamorphism. During this stage, pegmatites have been rotated into the main Eoalpine foliation.

\subsection{P-T Conditions of Fluid Entrapment}

Homogenization temperatures of FIs were used to calculate fluid density isochores for the different types of host minerals that allow to constrain, for a given temperature range, a minimum in pressures for fluid trapping. Due to the intense Eoalpine metamorphic overprint of all pegmatites, P-T conditions for the Permian pegmatite emplacement can only be estimated with a considerable degree of uncertainty. However, the primary mineral assemblages in the investigated samples including coarse-grained K-feldspar, quartz muscovite, plagioclase, tourmaline, garnet, and in many cases spodumene indicate typical magmatic assemblages as products of crystallization during the Permian extensional event [26,27]. Additionally, Mn-rich garnets with euhedral to subhedral cores containing the lowest $\mathrm{Ca}$ contents are typical for magmatic garnet chemistry [53,54] (Figure 6). Smallest healed cracks and/or rims correspond to Ca-rich overgrowths as a result of Eoalpine deformation and metamorphism [6,55]. P-T conditions based on the presence of andalusite, but also of kyanite and sillimanite as mineral inclusions in magmatic garnet indicate variable, though moderate P-T conditions during the Permian event [27]. Minimum temperature conditions of $650{ }^{\circ} \mathrm{C}$ for magmatic crystallization of pegmatites in the Koralpe are based on solidus limits for andalusite in a melt-bearing peraluminous system [26]. Calculating conditions from the studied FI-types hamper constraints on P-T due to post-entrapment modifications and non-isochoric evolution of most of the primary inclusions in garnet, quartz, and spodumene. Inclusions in garnet and spodumene have a wide range in homogenization temperatures and contain a high number of solids that have been partly formed by in-situ mineral-host reactions (e.g., carbonates like rhodochrosite in garnet and zabuyelite in spodumene). They are therefore unsuitable for density estimates of host mineral crystallization. However, a particular exception of type-T1 FIs in tourmaline is suggested. FIs are primary, contain no solids, and do not visually indicate any modifications. In addition, type-T2 FIs from sample W04, showing slightly higher densities, have been added for comparison. Using representative isochores from FIs in tourmaline samples W04/05/06 with highest densities, minimum trapping pressures from $>4.0 \mathrm{kbar}$ at 650 to $5.5 \mathrm{kbar}$ at $750{ }^{\circ} \mathrm{C}$ are obtained (Figure 8).

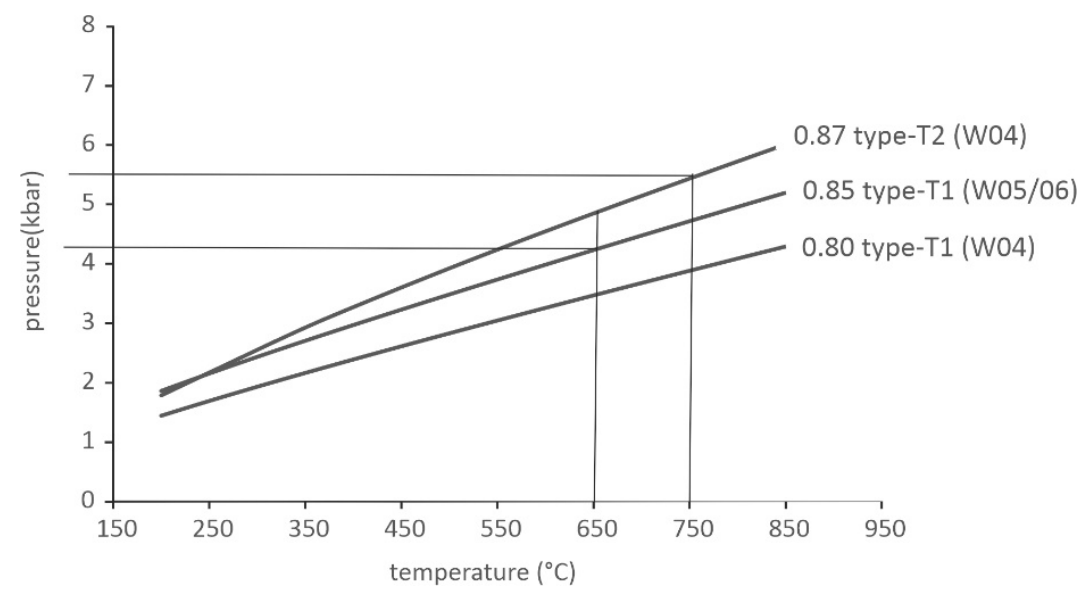

Figure 8. Estimated pressures for tourmaline crystallization calculated from Type-T1 and T2 density isochores of samples W04/05/06. Numbers correspond to the highest densities. The temperature range of $650-750{ }^{\circ} \mathrm{C}$ is based after Konzett et al. [9]. 
Estimated pressures are close to the proposed pressures of ca. $4 \mathrm{kbar}$ after Schuster et al. [11] for the Jenig Complex and $5.3 \pm 0.3 \mathrm{kbar}$ at $525 \pm 15{ }^{\circ} \mathrm{C}$ after Gaidies et al. [56] for the micaschist host rocks in close proximity of the Hohenwart spodumene pegmatite field in the northern areas of the KWS (WC in Figure 1a). This indicates at least crustal depths for pegmatite emplacement during metamorphism of the country rocks between 12 and $15 \mathrm{~km}$.

\subsection{Is the Proposed Chronology of Fluid Entrapment Representative to All Pegmatite Minerals of the Koralpe?}

It is shown that aqueous type-A FIs occur only in magmatic garnets of the Wirtbartl area, which represents the southernmost location of the studied pegmatite fields (Figure 1b). All other garnet samples further north of the Koralpe bear no aqueous FIs-primary FIs are of $\mathrm{CO}_{2}-\mathrm{N}_{2}$-chemistry. This is also valid for tourmaline (type-T1) and quartz (type-Q1). One possible reason could be that the aqueous part of the earliest magmatic fluid was partly consumed during the formation of hydrous silicates while prograde high-temperature metamorphism. Under the assumption that type-A occurs only in garnets of the Wirtbartl pegmatite field, an increasing trend in intensity of host-rock metamorphism from the south to the north in the Koralpe is possible. The host rock-enriched $\mathrm{CO}_{2}-\mathrm{N}_{2}$-rich fluid is present in all host mineral samples of the studied Koralpe pegmatite fields. However, continuous melt solidification formed mixtures of a $\mathrm{CO}_{2}-\mathrm{N}_{2}$ and $\mathrm{H}_{2} \mathrm{O}$-rich fluid that entrapped during late tourmaline and quartz growth and during spodumene crystallization. It is shown that the saline aqueous component acts beside $\mathrm{CO}_{2}$ as a major contributor to form in-situ mineral reactions in the FIs, especially in cleavage-rich spodumene crystals. This means that pervasive host-rock metamorphism (of metasediments) during pegmatite crystallization works under open-system conditions, especially with regard to the aqueous component, in order to infiltrate pegmatite minerals by the continual influx of an aqueous fluid with lower salinity. An increase in fluid activity of $\mathrm{H}_{2} \mathrm{O}$ leads to a fluid with decreased salinities that was trapped as a mixed fluid along with open fractures and cleavage planes in host minerals of the pegmatites. This in turn lowers the solvus of the $\mathrm{CO}_{2}-\mathrm{N}_{2}-\mathrm{H}_{2} \mathrm{O}$ fluid system to slightly lower conditions where spodumene crystallization occurred.

\section{Conclusions}

Primary FIs in magmatic garnets, tourmaline, quartz, and spodumene provide direct evidence for a complex $\mathrm{CO}_{2}-\mathrm{N}_{2}-\mathrm{H}_{2} \mathrm{O}-\mathrm{NaCl}-\mathrm{CaCl}_{2}$-fluid present during crystallization of granitic pegmatites in the crystalline basement of the Koralpe (Eastern Alps). This fluid chemistry, also dominant in FIs from Permian pegmatites of the Texel Complex west of the Tauern Window (Figure 1a), reflects high $\mathrm{N}_{2}$ fluid contents, as well, indicative of a source of $\mathrm{N}$ in the parent melt that evolved during melt solidification from the metapelitic host rocks [23]. Components from this fluid originate from the interplay between a magmatic granitoid $\left(\mathrm{H}_{2} \mathrm{O}\right)$ and a high-grade metamorphic $\left(\mathrm{CO}_{2}-\mathrm{N}_{2} \pm \mathrm{CH}_{4}\right)$ fluid that, based on its sequential occurrence, enables a chronology of pegmatite mineral crystallization. The distribution of FI types indicates that during an early fluid stage 1, controlled by an unmixed fluid, a low-saline $\mathrm{H}_{2} \mathrm{O}-\mathrm{NaCl}-\mathrm{CaCl}_{2}$-rich fluid together with a $\mathrm{CO}_{2}-\mathrm{N}_{2}$-rich fluid was entrapped significantly earlier as a two-end member fluid before both components reached their mixing stage at the solvus (fluid stage 2). The mixed $\mathrm{H}_{2} \mathrm{O}$ and $\mathrm{CO}_{2}-\mathrm{N}_{2}$-rich fluid are not observed in garnets, indicating that magmatic garnet crystallized earlier compared to tourmaline and quartz. The presence of this fluid in spodumene crystals further implies that spodumene crystallization occurred after garnet but coevally with latestage growth of tourmaline and quartz under solidification of the peraluminous granitic melt (Figure 7).

To conclude, pegmatite formation in the Koralpe is considered as the result of crustal anatexis by partial melting of Al-rich metapelites during the Permo-Triassic low-P/high-T tectonometamorphic event, as previously proposed for the Permian pegmatite field of the Texel Complex in Northern Italy [8,9]. Estimated P-T conditions from primary nonmodified FIs in tourmaline of $4.5-5.5 \mathrm{kbar}$ at $650-750^{\circ} \mathrm{C}$ are in line with the P-T range of ca. 4-5 kbar at $650{ }^{\circ} \mathrm{C}$ after Gaidies et al. [56] and Schuster et al. [11] for the emplacement 
of pegmatites distributed throughout the KWS of the Eastern Alps. FIs depart from the presumption that all of the Permian pegmatite hosting FIs have been re-equilibrated during Eoalpine deformation and metamorphism.

Author Contributions: Conceptualization, K.K.; methodology, K.K., M.H. and A.M.; field work and sample collection, K.K., M.H. and A.M.; data analysis K.K., M.H. and A.M.; first draft preparation, K.K.; data curation, K.K., M.H. and A.M.; reviewing and editing, K.K., M.H. and A.M. All authors have read and agreed to the published version of the manuscript.

Funding: Open Access Funding by the University of Graz.

Data Availability Statement: Not applicable.

Acknowledgments: The author highly appreciates W. Postl for his cooperation in providing pegmatite samples from Wirtbartl pegmatite field. F. Walter is thanked for spodumene samples from the Klementkogel. Many thanks go to Sara Raič for her support in analyzing garnet chemistries. The authors thank four anonymous reviewers for their careful and constructive reviews.

Conflicts of Interest: The authors declare no conflict of interest.

\section{References}

1. Thöni, M.; Miller, C. Permo-Triassic pegmatites in the eo-Alpine eclogite-facies Koralpe complex, Austria: Age and magma source constraints from mineral chemical, $\mathrm{Rb}-\mathrm{Sr}$ and $\mathrm{Sm}-\mathrm{Nd}$ isotope data. Schweiz. Mineral. Petrog. Mitt. 2000, 80, 169-186.

2. Schuster, R.; Scharbert, S.; Abart, R.; Frank, W. Permo-Triassic extension and related HT/LP metamorphism in the AustroalpineSouthalpine realm. Mitt. Ges. Geol. Bergbaustud. Österr. 2001, 45, 111-141.

3. Rebay, G.; Spalla, M. Emplacement at granulite facies conditions of the Sesia-Lanzo metagabbros: An early record of Permian rifting? Lithos 2001, 58, 85-104. [CrossRef]

4. Schuster, R.; Stüwe, K. The Permian Metamorphic Event in the Alps. Geology 2008, 36, 603-606. [CrossRef]

5. Kunz, B.E.; Manzotti, P.; von Niederhäusern, B.; Engi, M.; Darling, J.R.; Giuntoli, F.; Lanari, P. Permian high-temperature metamorphism in the Western Alps (NW Italy). Int. J. Earth Sci. 2018, 107, 203-229. [CrossRef]

6. Knoll, T.; Schuster, R.; Huet, B.; Mali, H.; Onuk, P.; Horschinegg, M.; Ertl, A.; Giester, G. Spodumene pegmatites and related leucogranites from the Austroalpine unit (Eastern Alps, Central Europe): Field relations, petrography, geochemistry and geochronology. Can. Mineral. 2018, 56, 489-528. [CrossRef]

7. Schuster, R.; Huet, B.; Knoll, T.; Paulick, H. Anatectic origin of albite-spodumene pegmatites: A geochemical model. Geophys. Res. Abstr. 2019, 21, 2019-7277.

8. Konzett, J.; Schneider, T.; Nedyalkova, L.; Hauzenberger, C.; Melcher, F.; Gerdes, A.; Whitehouse, M. Anatectic Granitic Pegmatites from the Eastern Alps: A case of variable Rare-metal enrichment during high-grade regional metamorphism-I: Mineral assemblages, geochemical characteristics, and emplacement ages. Can. Mineral. 2018a, 56, 555-602. [CrossRef]

9. Konzett, J.; Hauzenberger, C.; Ludwig, T.; Stalder, R. Anatectic Granitic Pegmatites from the Eastern Alps: A case of variable Rare-metal enrichment during high-grade regional metamorphism-II: Pegmatite staurolite as an indicator of anatectic pegmatite parent melt formation—a field and experimental study. Can. Mineral. 2018b, 56, 603-624. [CrossRef]

10. Schmid, S.M.; Fügenschuh, B.; Kissling, E.; Schuster, R. Tectonic map and overall architecture of the Alpine orogeny. Eclog. Geol. Helv. 2004, 97, 93-117. [CrossRef]

11. Schuster, R.; Tropper, P.; Krenn, E.; Finger, F.; Frank, W.; Philippitsch, R. Prograde Permo-Triassic metamorphic HT/LP assemblages from the Austroalpine Jenig Complex (Carinthia, Austria). Austrian J. Earth Sci. 2015, 108, 73-90. [CrossRef]

12. London, D. Magmatic-hydrothermal transition in the Tanco rare-element pegmatite: Evidence from fluid inclusions and phaseequilibrium experiments. Am. Mineral. 1986, 71, 376-395.

13. Whitworth, M.P.; Rankin, A.H. Evolution of fluid phases associated with lithium pegmatites from SE Ireland. Miner. Mag. 1989, 53, 271-284. [CrossRef]

14. Linnen, R.L.; Williams-Jones, A.E. The evolution of pegmatite-hosted Sn-W mineralization at Nong Sua, Thailand: Evidence from fluid inclusions and stable isotopes. Geochim. Cosmochim. Acta 1994, 58, 735-747. [CrossRef]

15. Beurlen, H.; Da Silva, M.R.R.; De Castro, C. Fluid origin and evolution during the formation of rare-element pegmatites from the Borborema Province, Northern Brazil. Rev. Bras. Geociências 2000, 30, 331-336. [CrossRef]

16. Fuertes-Fuente, M.; Martin-Izard, A.; Boiron, M.C.; Viñuela, J.M. P-T Path and Fluid Evolution in the Franqueira Granitic Pegmatite, Central Galicia, Northwestern Spain. Can. Mineral. 2000, 38, 1163-1175. [CrossRef]

17. Masoudi, F.; Yardley, B.W.D. Magmatic and Metamorphic Fluids in Pegmatite Development: Evidence from Borujerd Complex, Iran. J. Sci. Islamic Repub. Iran 2005, 16, 43-53.

18. Rickers, K.; Thomas, R.; Heinrich, W. The behavior of trace elements during the chemical evolution of the $\mathrm{H}_{2} \mathrm{O}-$, , B-, and F-rich granite-pegmatite-hydrothermal system at Ehrenfriedersdorf, Germany: A SXRF study of melt and fluid inclusions. Miner. Depos. 2006, 41, 229-245. [CrossRef] 
19. Thomas, R.; Davison, P.; Beurlen, H. The competing models for the origin and internal evolution of granitic pegmatites in the light melt and fluid inclusion research. Miner. Petrol. 2012, 106, 55-73. [CrossRef]

20. Thomas, R.; Davison, P. Revisiting complete miscibility between silicate melts and hydrous fluids, and the extreme enrichment of some elements in the supercritical state-consequences for the formation of pegmatites and ore deposites. Ore Geol. Rev. 2016, 72, 1088-1101. [CrossRef]

21. Fredriksson, J. Fluid Inclusion and Trace-Element Analysis of the Rare-Element Pegmatite Bodies Altim and Tamanduá from the Borborema Province, Brazil. Master's Thesis, University of Helsinki, Helsinki, Finland, 2017.

22. Thomas, A.V.; Spooner, E.T.C. Fluid inclusions in the systems $\mathrm{H}_{2} \mathrm{O}-\mathrm{CH}_{4}-\mathrm{NaCl}-\mathrm{CO}_{2}$ from metasomatic tourmaline within the border unit of the Tanco zoned granite pegmatite, S.E. Manitoba. Geochim. Cosmochim. Acta 1988, 52, 1065-1075. [CrossRef]

23. Krenn, K.; Konzett, J.; Stalder, R. Anatectic granitic pegmatites from the eastern Alps: A case of variable rare metal enrichment during high-grade regional metamorphism. III: Fluid inclusions as potential indicators for anatectic pegmatite parent melt formation. Can. Mineral. 2021, in press.

24. Huff, T.A.; Nabelek, P.I. Production of carbonic fluids during metamorphism of graphitic pelites in a collisional orogeny-An assessment from fluid inclusions. Geochim. Cosmochim. Acta 2007, 71, 4997-5015. [CrossRef]

25. Beck-Mannagetta, P. 188 Wolfsberg, Geological Map of Austria 1:50,000; Geological Survey of Austria: Vienna, Austria, 1980.

26. Habler, G.; Thöni, M.; Miller, C. Major and trace element chemistry and Sm-Nd age correlation of magmatic pegmatite garnet overprinted by eclogite-facies metamorphism. Chem. Geol. 2007, 241, 4-22. [CrossRef]

27. Thöni, M.; Miller, C.; Zanetti, A.; Habler, G.; Goessler, W. Sm-Nd isotope systematics of high-REE accessory minerals and major phases: ID-TIMS, LA-ICP-MS and EPMA data constrain multiple Permian-Triassic pegmatite emplacement in the Koralpe, Eastern Alps. Chem. Geol. 2008, 254, 216-237. [CrossRef]

28. Miller, C.; Thöni, M.; Konzett, J.; Kurz, W.; Schuster, R. Eclogites from the Koralpe and Saualpe type-localities, Eastern Alps, Austria. Mitt. Österr. Miner. Ges. 2005, 150, 227-263.

29. Tenczer, V.; Stüwe, K. The metamorphic field gradient in the eclogite type locality Koralpe region, Eastern Alps. J. Metam. Geol. 2003, 21, 377-393. [CrossRef]

30. Thöni, M. Dating eclogite-facies metamorphism in the Eastern Alps—approaches, results, interpretations: A review. Miner. Petrol. 2006, 88, 123-148. [CrossRef]

31. Göd, R. The spodumene deposit at "Weinebene", Koralpe, Austria. Miner. Depos. 1989, 24, 270-278. [CrossRef]

32. Niedermayr, G.; Göd, R. Das Spodumenvorkommen auf der Weinebene und seine Mineralien. Carinthia II 1992, $182,21-35$.

33. Moser, B.; Postl, W.; Walter, F. Ein Beryll- und Spodumen führender Pegmatit vom Klementkogel, nördliche Koralpe, Steiermark. Mitt. Abt. Miner. Landesm. Joann. 1987, 53, 21-25.

34. Oakes, C.S.; Bodnar, R.J.; Simonson, T.M. The system $\mathrm{NaCl}-\mathrm{CaCl}_{2}-\mathrm{H}_{2} \mathrm{O}$ : The ice liquidus at 1 atm total pressure. Geochim. Cosmochim. Acta 1990, 54, 603-610. [CrossRef]

35. Duan, Z.; Møller, N.; Weare, J.H. A general equation of state for supercritical fluid mixtures and molecular dynamics simulation of mixture PVTX properties. Geochim. Cosmochim. Acta 1996, 60, 1209-1216. [CrossRef]

36. Naden, J. CalcicBrine: A Microsoft Excel 5.0 Add-in for calculating salinities from microthermometric data in the system $\mathrm{NaCl}$ $\mathrm{CaCl}_{2}-\mathrm{H}_{2}$ O. In PACROFI VI; Brown, P.E., Hagemann, S.G., Eds.; University of Wisconsin-Madison: Madison, WI, USA, 1996; pp. 97-98.

37. Jacobsen, R.T.; Stewart, R.B.; Jahangiri, M. Thermodynamic properties of nitrogen from the freezing line to $2000 \mathrm{~K}$ at pressures to 1000 MPa. J. Phys. Chem. Ref. Data 1986, 15, 735-909. [CrossRef]

38. Bakker, R.J. Package FLUIDS 1 Computer programs for analysis of fluid inclusion data and for modelling bulk fluid properties. Chem. Geol. 2003, 194, 3-23. [CrossRef]

39. Diamond, L. Glossary: Terms and symbols used in fluid inclusion studies. In Fluid Inclusions: Analysis and Interpretation; Samson, I., Anderson, A., Marshall, D., Eds.; Mineralogical Association of Canada Short Course Series; Mineralogical Association of Canada: Ottawa, ON, Canada, 2003; Volume 32, pp. 365-374.

40. Davis, D.W.; Lowenstein, T.K.; Spencer, R.J. Melting behaviour of fluid inclusions in laboratory-grown halite crystals in the systems NaCl- $\mathrm{H}_{2} \mathrm{O}, \mathrm{NaCl}-\mathrm{KCl}-\mathrm{H}_{2} \mathrm{O}, \mathrm{NaCl}-\mathrm{MgCl}_{2}-\mathrm{H}_{2} \mathrm{O}$, and $\mathrm{NaCl}-\mathrm{CaCl}_{2}-\mathrm{H}_{2} \mathrm{O}$. Geochim. Cosmochim. Acta 1990, 54, 591-601. [CrossRef]

41. Goldstein, R.H.; Reynolds, T.J. Systematics of fluid inclusions in diagenetic minerals. In SEPM Short Course; SEPM: Tulsa, OK, USA, 1994; Volume 31.

42. Bodnar, R.J. Introduction to aqueous-electrolyte fluid inclusions. In Fluid Inclusions: Analysis and Interpretation; Samson, I., Anderson, A., Marshall, D., Eds.; Mineralogical Association of Canada Short Course Series; Mineralogical Association of Canada: Ottawa, ON, Canada, 2003; Volume 32, pp. 81-100.

43. Burke, E.A.J. Raman microspectrometry of fluid inclusions. Lithos 2001, 55, 139-158. [CrossRef]

44. Frezzotti, M.L.; Tecce, F.; Casagli, A. Raman spectroscopy for fluid inclusion analysis. J. Geochem. Explor. 2012, 112, 1-20. [CrossRef]

45. Whitney, D.L.; Evans, W.E. Abbreviations for names of rock-forming minerals. Am. Mineral. 2010, 95, 185-187. [CrossRef]

46. Frezzotti, M.L.; Touret, J.L.R. $\mathrm{CO}_{2}$, carbonate-rich melts and brines in the mantle. Geosci. Front. 2014, 5, 697-710. [CrossRef]

47. Anderson, A.J.; Clark, A.H.; Gray, S. The occurrence and origin of zabuyelite $\left(\mathrm{Li}_{2} \mathrm{CO}_{3}\right)$ in spodumene-hosted fluid inclusions: Implications for the internal evolution of rare-element granitic pegmatites. Can. Mineral. 2001, 39, 1513-1527. [CrossRef] 
48. Anderson, A.J. Microthermometric behavior of crystal-rich inclusions in spodumene under confining pressure. Can. Mineral. 2019, 57, 853-865. [CrossRef]

49. Moine, B.; Guillot, C.; Gibert, F. Controls of the composition of nitrogen-rich fluids originating from reaction with graphite and ammonium-bearing biotite. Geochim. Cosmochim. Acta 1994, 58, 5503-5523. [CrossRef]

50. Diamond, L.W. Review of the systematics of $\mathrm{CO}_{2}-\mathrm{H}_{2} \mathrm{O}$ fluid inclusions. Lithos 2001, 55, 69-99. [CrossRef]

51. Roedder, E. Fluid Inclusions. In Reviews in Mineralogy; Mineralogical Society of America: Chantilly, VA, USA, 1984; Volume 12, 400p.

52. Krenn, K.; Huong, L.T.T. Fluid characteristics from shallow magmatic environments: A contribution to danburite bearing Luc Yen pegmatites, Northern Vietnam. Vietnam J. Earth Sci. 2019, 41, 1-9. [CrossRef]

53. Selway, J.B.; Breaks, F.W.; Tindle, A.G. A review of rare element (Li-Cs-Ta) pegmatite exploration techniques for the Superior Province, Canada and large worldwide tantalum deposits. Explor. Min. Geol. 2005, 14, 1-30. [CrossRef]

54. London, D. Pegmatites. Can. Mineral. Spec. Publ. 2008, 10, 347.

55. Proyer, A. The preservation of high-pressure rocks during exhumation: Metagranites and metapelites. Lithos 2003, 70, 183-194. [CrossRef]

56. Gaidies, F.; Abart, R.; De Capitani, C.; Schuster, R.; Connolly, A.D.; Reusser, E. Characterization of polymetamorphism in the Austroalpinebasement east of the Tauern Window using garnet isopleth thermobarometry. J. Metamorph. Geol. 2006, 24, 451-475. [CrossRef] 